Darja Radović Mahečić

Samostalni istraživač, Zagreb - Ženeva

\title{
Potez triju trgova (Trg hrvatskih velikana - Trg žrtava fašizma - Krešimirov trg) - urbani status istočne ekstenzije zagrebačkoga Donjeg grada
}

\author{
Izvorni znanstveni rad - Original scientific paper \\ Primljen - Received 20. 10. 2020. \\ UDK 711.4:711.61](497.5Zagreb) \\ DOI doi.org/10.31664/ripu.2020.44/2.10
}

\begin{abstract}
Sažetak
Detaljno se predstavlja urbanistički i arhitektonski razvoj istočnoga gradskog središta, čiju okosnicu čini potez triju trgova: Trga hrvatskih velikana, Trga žrtava fašizma i Krešimirova trga. Urbani status ovog područja stjecao se postupnim razvojem predjela koji se nazivao "dio istočno od Draškovićeve ulice", što je na prijelazu 19. u 20. stoljeće značilo izvan okvira Innenstadta (»unutarnjeg grada", odnosno gradskog središta). Autor ideje trgova na dijagonalnoj osi je Milan Lenuci, najpoznatiji zagrebački urbanist s kraja 19. i početka 20. stoljeća, koji je prvi istaknuo razvojne mogućnosti tog dijela grada. Detaljnom regulatornom osnovom 1905. zadao je ključne elemente predjela Vlaška - Draškovićeva - Branimirova - Bauerova, koji je realiziran zbrojem pojedinačnih gradnji $i$
\end{abstract}

parcijalnih regulacija većinom 1920-ih i 1930-ih godina. Širenje grada prema istoku od početka 20. stoljeća (kada grad bitno pomiče svoju granicu u tom smjeru), intenzivna i kvalitetna izgradnja u meduratnom razdoblju (kada taj prostor postaje "novi" poslovno-stambeni dio grada), ali i dogradnja 1950-ih i 1960-ih godina, bili su smisleniji, urbanistički odredeniji te prostorno i hortikulturno primjereniji negoli u drugim gradskim područjima, što ovoj gradskoj četvrti daje identitet i prepoznatljivost, karakterističnu cjelovitost $i$ visoku ambijentalnu vrijednost. Poštivanje toga reprezentativnog urbanog prostora, koji je nastao angažmanom brojnih aktera u relativno kratkom segmentu 20. stoljeća, treba ugraditi u obvezni dio programa buduće sanacije i uređenja.

Ključne riječi: Zagreb, urbanizam, regulatorne osnove, Milan Lenuci, Regulatorna osnova za istočni dio grada 1905., klasični modernizam 1920-ih, međuratna arhitektura, interpolacija

Potez triju trgova - Trga hrvatskih velikana, Trga žrtava fašizma i Trga Petra Krešimira IV. - okosnica je istočnoga gradskog središta. Urbani status te ekstenzije Donjega grada stjecao se evolucijom predjela koji se u regulacijama nazivao »dio istočno od Draškovićeve ulice«, što je na prijelazu 19. u 20. stoljeće još značilo izvan okvira Innenstadta (»unutarnjeg grada«), tj. izvan gradskog središta. Autor ideje trgova na dijagonalnoj osi je najvažniji onodobni zagrebački urbanist - Milan Lenuci, koji je prvi istaknuo razvojne mogućnosti tog dijela grada. Detaljnom regulatornom osnovom 1905. (koja, istina, nije bila prihvaćena) zadao je ključne elemente predjela koji je realiziran zbrojem pojedinačnih zahvata 1920-ih i 1930-ih godina.

Širenje grada prema istoku od početka 20. stoljeća (kada mu se granica bitno pomiče u tom smjeru) te intenzivna i kvalitetna gradnja u međuratnom razdoblju (kada taj prostor postaje nova poslovno-stambena zona), bili su urbanistički, prostorno i hortikulturno razrađeni parcijalnim regulacijama. Vizualni kontakti sa starom gradskom jezgrom i velik broj izuzetnih arhitektonskih ostvarenja dali su ovoj gradskoj četvrti identitet i prepoznatljivost te višeslojnu kulturno-povijesnu vrijednost. Angažmanom brojnih aktera u relativno kratkom segmentu 20. stoljeća nastao je jedan od najreprezentativnijih ambijenata urbane fizionomije Zagreba.

\section{Prostorni razvoj predjela Vlaška - Draškovićeva - Branimirova - Bauerova od kraja 19. do početka 20. stoljeća}

Povijesnu Vlašku ulicu, kojom se tradicionalno s istoka promet dovodi u središte grada, nalazimo na Nacrtu grada Zagreba 1864., podlozi prve regulatorne osnove. ${ }^{1}$ Detaljno je prikazana izgrađenost u trenutku kada je grad dobio že- 


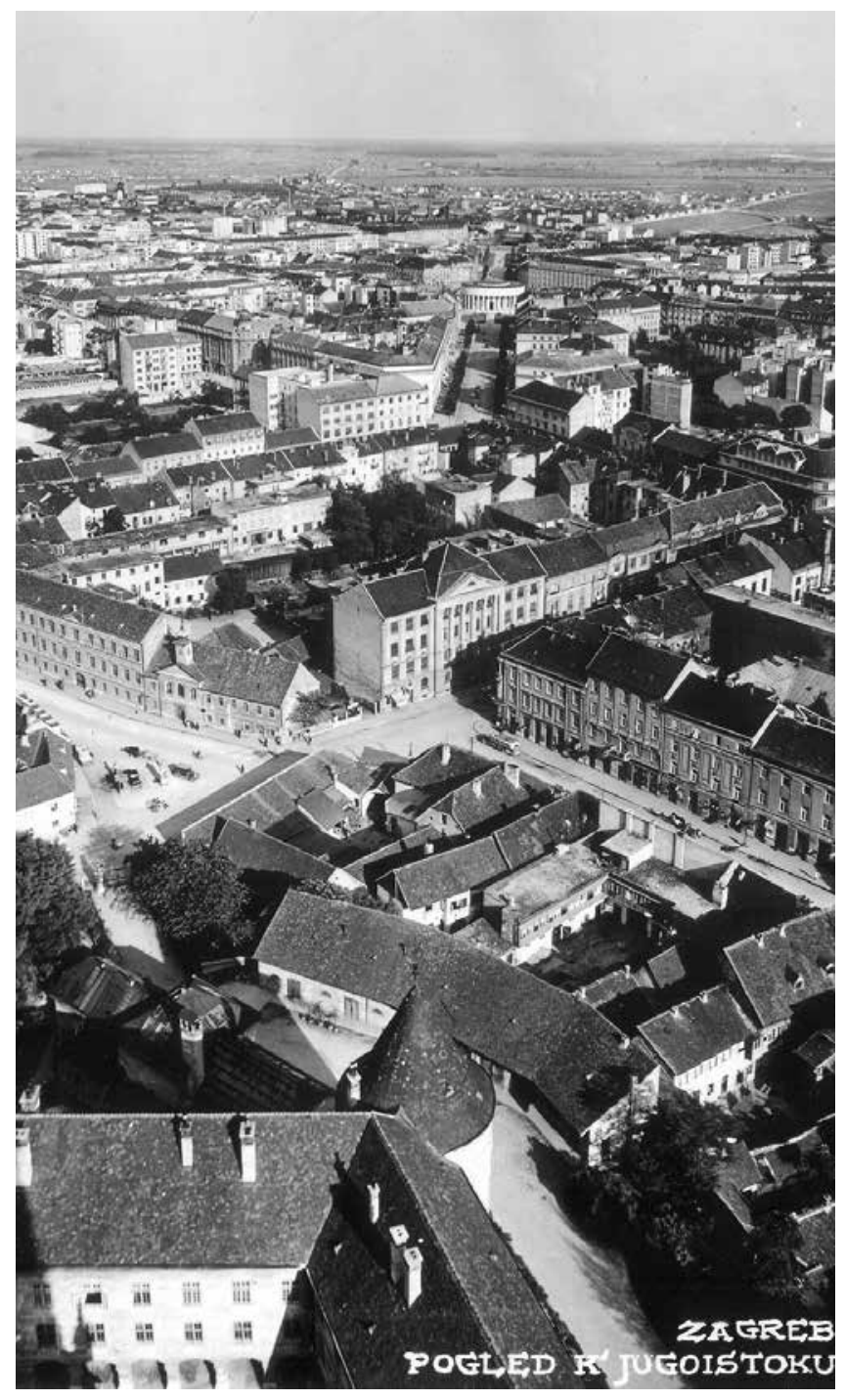

1. Potez tri trga u perspektivi pogleda s katedrale, oko 1938. (razglednica)

View of the three squares from the Zagreb Cathedral tower, around 1938 ljeznicu, a grafički su izdvojene zgrade javne namjene. Na sjevernoj strani Vlaške označene su Vojnička bolnica (Vlaška 87) i crkva sv. Petra, a na južnoj posjed biskupa Maksimilijana Vrhovca (od kojeg se sačuvala vrtlarska kućica Vlaška 72) i Gradska klaonica u Bauerovoj ulici, građevine koje su prve odredile hibridni karakter ovog dijela grada. Ambiciozna Prva regulatorna osnova grada 1865 . tek planira ulice sjever-jug istočnije od povijesne Petrinjske, poput Palmotićeve i Draškovićeve, a zadanim prostorom dominira neregulirani potok Medveščak. U Obrazloženju osnove njegovo se premoštenje, zbog čestih poplava, nečistoće i opasnosti od zaraza, ističe kao preduvjet za širenje grada u smjeru jugoistoka. ${ }^{2}$ Nacrt grada iz 1878. prvi registrira tzv. budimpeštansku prugu, koja u smjeru zapad-istok presijeca grad. Planira se ortogonalna mreža ulica Donjega grada, a na istoku u produženoj Jurišićevoj, buduća Martićeva, sve do Bauerove. ${ }^{3}$

Druga regulatorna osnova Zagreba iz 1887., koncentrirana je na skup odluka o cestama i rešetkasti raster kao metodu širenja, planira za prostor i na istoku grada do onodobne njegove granice na potoku Laščinščaku. Prazna veća zemljišta rezervirana su za topničku i konjaničku vojarnu te smještaj triju trgova: na istočnoj strani Draškovićeve planiran je veliki Trg D, na zapadnoj strani potoka Laščinščaka manji Trg E, a u tijesnom pojasu između Branimirove ulice i same željezničke pruge Trg F, bez posebnog pojašnjenja njihove namjene ili oblikovanja. ${ }^{4}$ Odredbe regulacije koje se ne tiču odluka o cestama govore o režimu voda i odnose se na reguliranje potoka, ponajviše zbog zaštite Donjega grada. Iako se tom regulatornom osnovom ukazalo na potencijal gradskog istoka, glavna zapreka širenju u tom smjeru i dalje je bio potok Medveščak.

2. Druga regulatorna osnova grada Zagreba iz 1887. ukazuje na potencijal gradskog istoka, detalj (Muzej grada Zagreba)

The Second Regulatory Plan for Zagreb (1887), detail, indicating the potential of the east fringe of the city

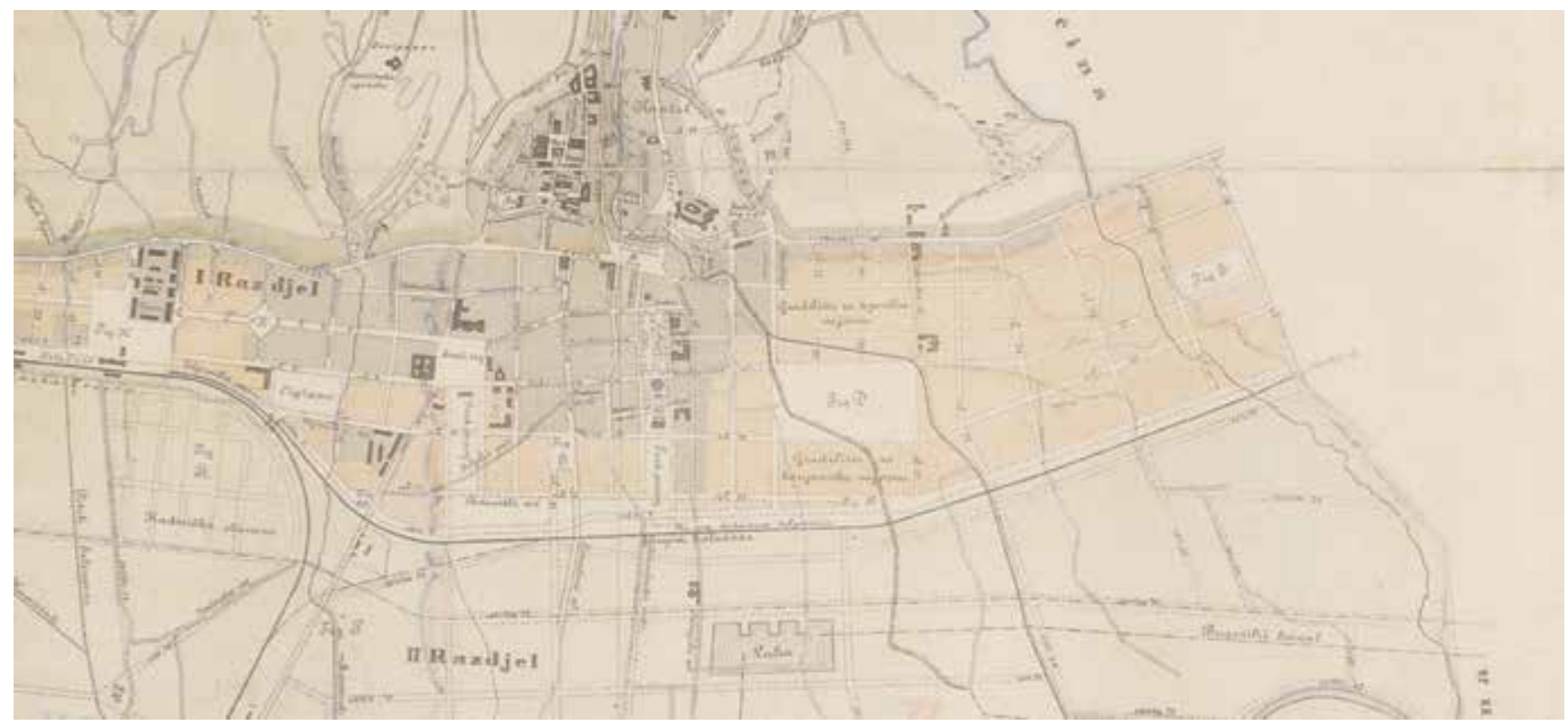




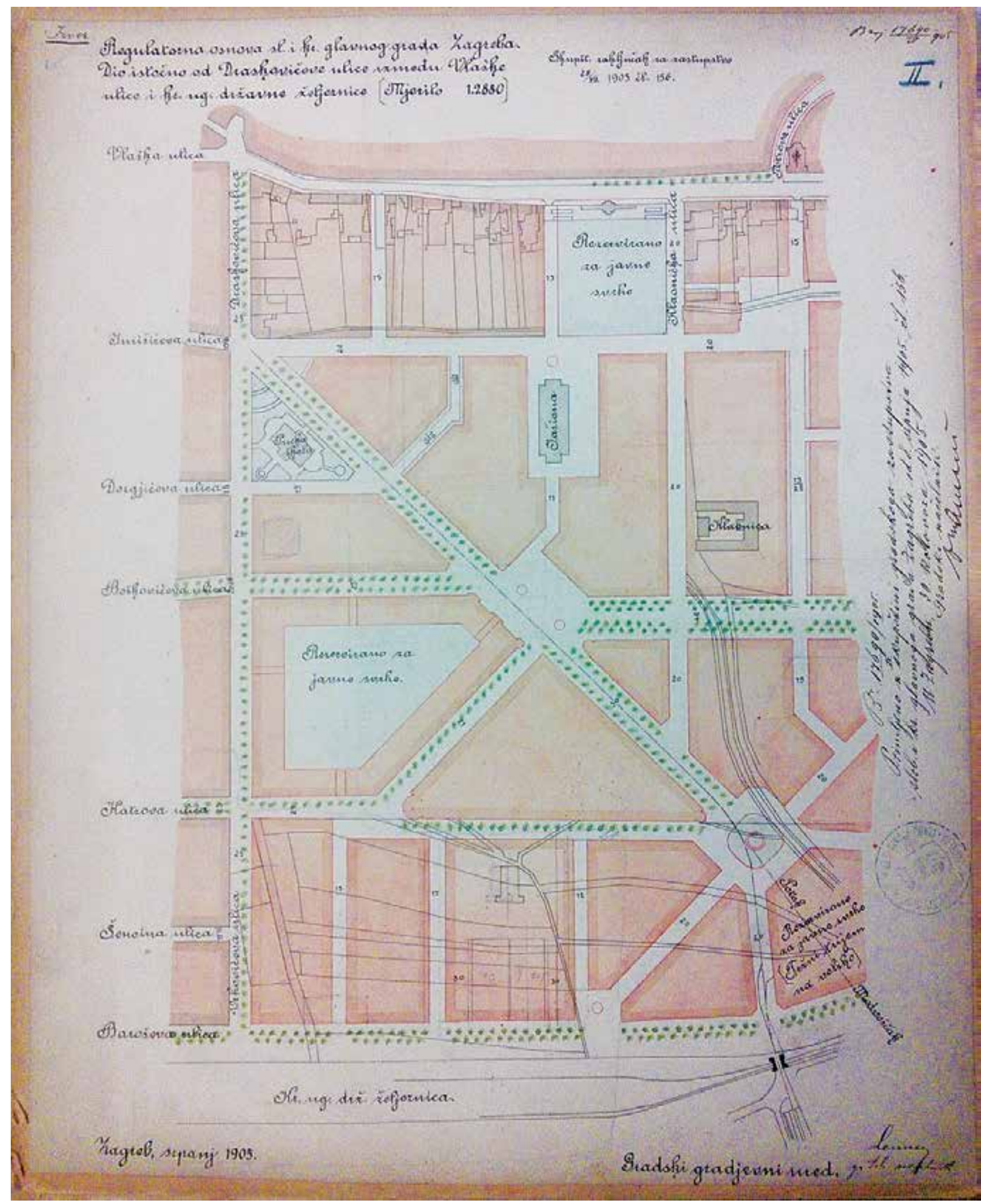

3. Regulatorna osnova slob. i kralj. Glavnog grada Zagreba. Dio istočno od Draškovićeve ulice izmedju Vlaške ulice i kr. ug. državne željeznice Milana Lenucija iz srpnja 1905. (Državni arhiv u Zagrebu), ključni urbanistički plan za istočni dio grada

Regulatory Plan for the Free Royal City of Zagreb. The area east of Draškovićeva Street between Vlaška Street and the Royal State Railways, designed by Milan Lenuci in July 1905, was the decisive urban development plan for the eastern part of the city 
Draškovićeva je u procesu širenja grada prema istoku imala svojevrsnu ulogu granice. Nakon što je Sajmište preseljeno sa Sveučilištnog trga (danas Trg Republike Hrvatske) na njezinu istočnu stranu (na zemljište planiranog Trga D između dviju vojarni), izgledalo je da će postati rub urbaniziranog dijela grada, pun fizičkih barijera. Zahvaljujući Lenuciju, izbjeći će se gradnja vojarni, ali će Draškovićeva ostati crta razdvajanja dviju etapa razvoja: na zapadnoj strani historicističkoga Donjeg grada, eminentno ortogonalnoga urbanog sustava koji se gradio do Prvoga svjetskog rata, a na istočnoj mahom međuratnog Zagreba koji će rasti na jedan drugi način, deklarirajući se za planiranje humanoga urbanog ambijenta. ${ }^{5}$ Taj istočni Zagreb traži diferenciran sustav komunikacija, odbacuje kvadratične sheme, traži slikovitost uličnih linija i proširuje pojam javnog prostora i zelenila.

Nacrt grada Zagreba 1898. prikazuje realno stanje onodobne izgrađenosti (sada već prepoznatljiv perivojni okvir Zelene potkove $s$ javnim zgradama u središtu, Strojarnicu državne željeznice južno od pruge, Tvornicu papira u budućoj industrijskoj zoni na Zavrtnici itd.), te prvi bilježi snažnu dijagonalu reguliranog potoka Medveščaka. ${ }^{6}$ To hidrotehničko rješenje zadalo je smjer Radijalne ulice (Ulice Franje Račkoga) koja će postati ulaz u novi istočni dio grada, ${ }^{7}$ a čiji je budući epicentar Trg žrtava fašizma. Prva građevina koja usvaja dominantnu kosu crtu Ulice Račkoga jest Pučka škola Gradskoga građevnog ureda (Hönigsberg i Deutsch, Račkoga 4 - Draškovićeva 17, 1901.). A da će ovaj predio postati poprište izgradnje obrazovnih ustanova (koje će nerijetko biti ustupljene za druge svrhe) potvrdila je na susjednoj južnoj parceli Viša djevojačka škola Vincenza Rauschera (današnja Traumatološka bolnica, Draškovićeva 19, 1907./08.). Obje škole s dvorištima, opasane visokim ogradama, prikazane su na secesijskom Nacrtu grada Zagreba $1911 .{ }^{8}$ Gospodarska izložba održana na mjestu buduće Burze 1906. i službeno je afirmirala taj gradski predio.

Regulacijom potoka Medveščaka omogućeno je urbanističko planiranje grada prema perivoju Maksimiru na istoku i željezničkoj pruzi na jugu. Nad vladinim zahtjevom za širenjem grada prema jugu Lenuci je prednost dao širenju na istok, jer između željezničke pruge i Save, za to još nisu bili stvoreni potrebni uvjeti. ${ }^{9}$ Regulatorna osnova slob. $i$ kralj. Glavnog grada Zagreba. Dio istočno od Draškovićeve ulice izmedju Vlaške ulice i kr. ug. državne željeznice 1905., kojom je obuhvaćen prostor između Vlaške, Draškovićeve, Baroševe (Branimirove) i Klaoničke (Bauerove), prvi je kvalitetan urbanistički plan koji je ambiciozno najavio razvojne mogućnosti ovog dijela grada. Budući da je stara gradnja već nastajala uz potez tradicionalne komunikacije Vlaške ulice, a velik dio zemljišta uz Klaoničku bio je »rezerviran za javne svrhe«, blok s Martićevom ne okupira previše Lenucijevu detaljnu regulaciju. Nova gradska četvrt za njega počinje na uglu Jurišićeve i Draškovićeve ulice, a okosnica toga novog prostora je snažna dijagonala Ulice Franje Račkoga, koja vizualno ishodište na sjeverozapadu ima u tornjevima katedrale, a na jugoistoku uz prugu već je bio planiran prostor za »javne svrhe - tržni triem« (Branimirova tržnica). Duž te avenije Lenuci planira na nju okomito postavljen četvrtasti trg, budući Trg žrtava fašizma, i ovalno-zrakasti Krešimirov trg. Prvi je smješten na spoju najjačih prometnica: Račkoga i buduće Zvonimirove, no realizirani Trg žrtava fašizma dimenzijama, arhitekturom i prometnom važnošću nadrast će projekcije Milana Lenucija koji je ambicioznije planirao drugi, Krešimirov trg. ${ }^{10}$

Uime mekše organizacijske strukture Lenuci napušta logiku ortogonalne mreže ulica te planira manje i veće trapezne blokove. Uvodi i druge dijagonalne poteze (prethodnicu Mislavove, ali nešto istočnije od realizirane i samo u segmentu), te niz kraćih ulica uokolo Krešimirova i malog trga na spoju s Hatzovom. Na taj način razbija dotadašnju pravokutnu shemu te iako zadržava načelo blokovske izgradnje, stvara novi urbani koncept.

Iako se fokusirao na zadani segment gradskog zemljišta koji je prvi trebalo prirediti za građenje, Lenuci proširuje zahvat. Smatrajući da svaki gradski predio treba imati prometnu žilu kucavicu (koja vodi glavni promet između središta grada i okoliša), stvara Regulatornu osnovu 1909. za najvažnije ulice i trgove istočnog područja i taj golemi neizgrađeni prostor nastoji na atraktivan način uključiti u tkivo grada. ${ }^{11}$ Između 1905. i 1909. godine radi seriju projekata za gradski istok, kojima su u fokusu dva specifična područja. Prvome je okosnica Ulica Franje Račkoga, a drugome Sjajna ulica - Zvonimirova, koja započinje na Trgu žrtava fašizma, a završava na ulazu u perivoj Maksimir.

Uz postojeću Vlašku i tek na svoj utilitarni, prometni karakter svedenu Branimirovu, reprezentativna Zvonimirova postaje element integracije zapad - istok, čija krivulja spaja srce grada i »najljepši, čovjekovom rukom priudešeni prirodni biser grada « - perivoj Maksimir. ${ }^{12}$ Detaljno razrađenim presjekom zadana je njezina širina ( $46 \mathrm{~m}$ ), ozelenjivanje dvostrukim drvoredima, planirane odvojene trake za tramvajski i automobilski promet te široki pločnici. Visina građevina na ovoj osi, kao i intenzitet izgrađenosti, opadaju prema istoku, tj. najzapadniji dijelovi građeni su zatvorenim trokatnim i četverokatnim gradskim blokovima, a najistočniji obiteljskim kućama u zelenilu (Peščenica).

Zadovoljavajući prvenstveno »zahtjeve prometa, higijene i ljepote (što mu je bilo omogućeno gotovo praznim zemljištem čiji je većinski vlasnik bila sama gradska općina), Lenuci inzistira na planiranju pojedinačnih kvalitetnih urbanih cjelina (trgova, širokih ulica, perivoja i zelenih površina) u skladu s naprednim shvaćanjima epohe (Camilla Sittea, Raymonda Unwina, Karla Henricija).${ }^{13}$ Precizira hijerarhiju ulica planiranjem drvoreda i određivanjem njihovih širina, pa tako najširu Zvonimirovu slijedi dijagonala Račkoga Višeslavova (30 m), pa Držislavova (25 m), Draškovićeva (23 $\mathrm{m})$, ulice zapadno od većih trgova (21 m), Martićeva i Bauerova $(20 \mathrm{~m})$, dok su kao najuže bile planirane, danas upravo prometom preopterećene, Đorđićeva i Smičiklasova (15, tj. $10-15 \mathrm{~m}$ ), te ulice okomite na Branimirovu u najjužnijem pojasu uza željezničku prugu $(12-13 \mathrm{~m}){ }^{14}$

Do tog se doba već smjestila Jašiona u Martićevoj (koja će poslije adaptacijama biti pretvorena u sajmišni prostor $\mathrm{Za}-$ grebačkog zbora), a njoj nasuprot veliko zemljište (prijašnjeg Vrhovčeva posjeda) ostalo je rezervirano za javnu namjenu 


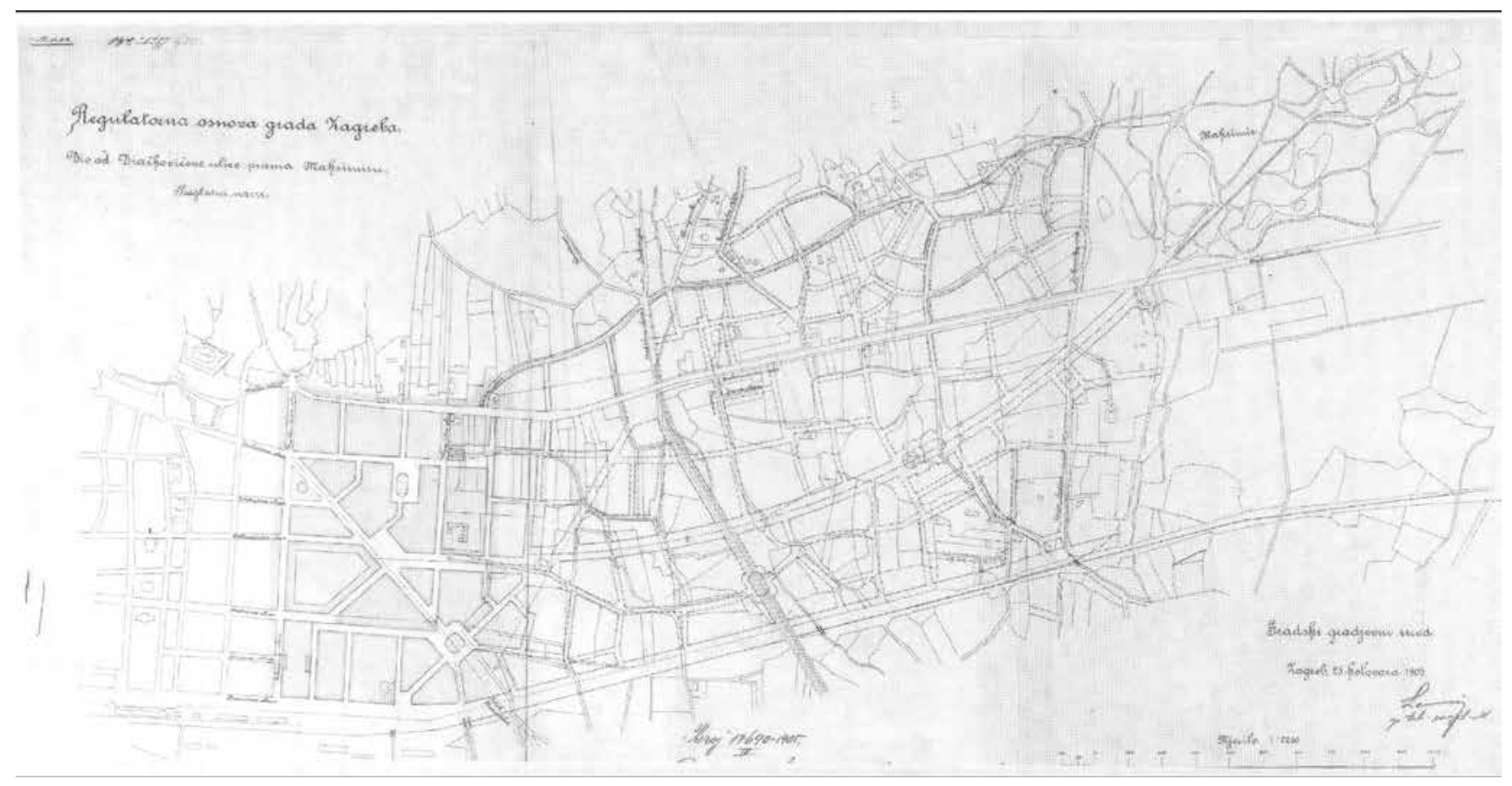

4. Regulatorna osnova grada Zagreba. Dio od Draškovićeve ulice prema Maksimiru Milana Lenucija iz 1909., generalni plan za komunikacije istočnog dijela grada (Državni arhiv u Zagrebu)

Milan Lenuci's 1909 Regulatory Plan for the City of Zagreb. A Segment from Draškovićeva Street to Maksimir - a master plan for all important communications in the east part of the city

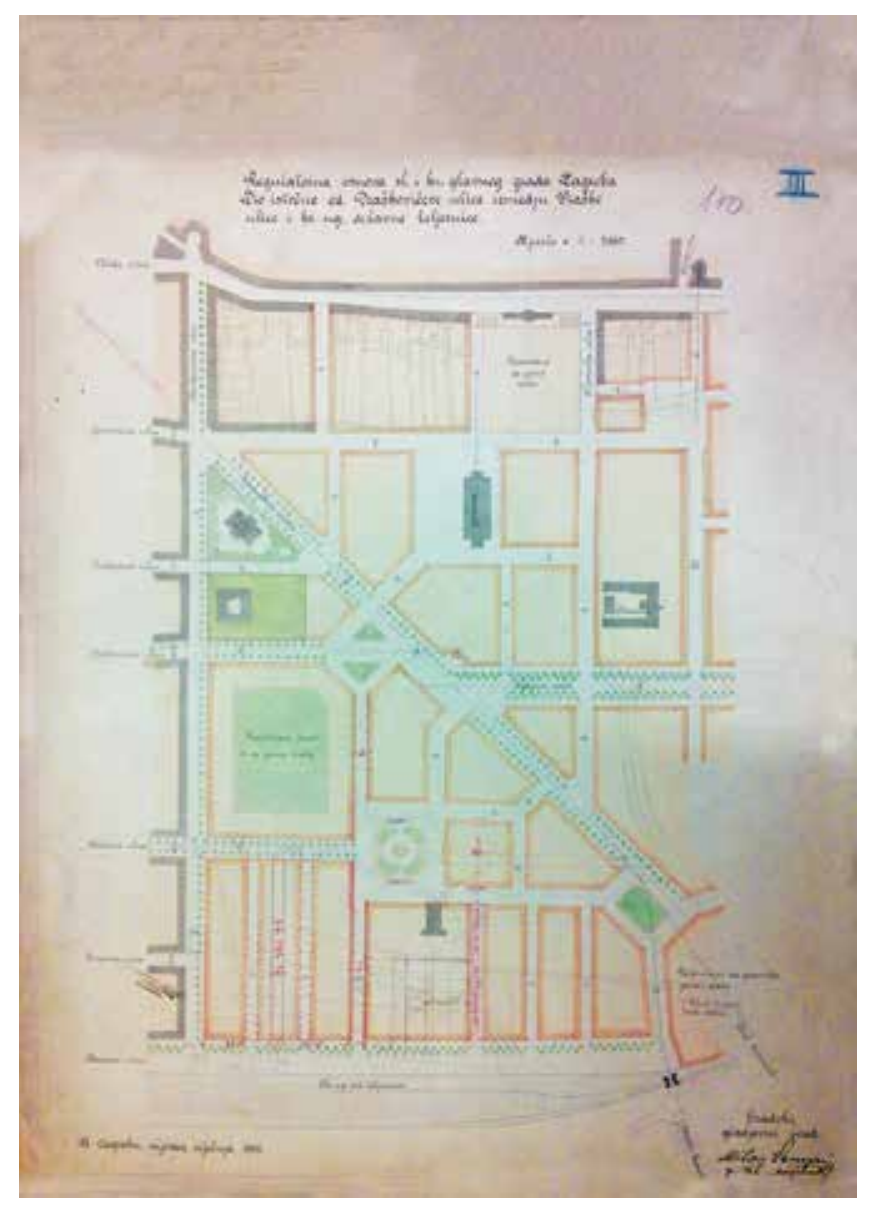

(budući stambeni sklop zagrebačke nadbiskupije). U nastojanju da područje bolje poveže s drugim kontaktnim zonama, Lenuci 1905. godine radi i Regulatornu osnovu za gradilište i cestu za Zemaljsku bolnicu na Šalati - Vončininu ulicu, tj. probija Vlašku ulicu i na sjevernoj strani ${ }^{15}$ jer traži da se prvo zauzimaju kvalitetniji gradski tereni, koje je trebalo cestama povezati i potom parcelirati. ${ }^{16}$

Lenucijeve varijante za dio grada istočno od Draškovićeve najviše se razlikuju u tretmanu južnoga i jugozapadnog dijela zahvata. Diskutabilan je, naime, bio spoj produžene Hatzove ulice (današnje Bornine) i Draškovićeve ulice, na čijoj je istočnoj strani Lenuci predlagao četvrtasti trg, dok je suprotstavljeni prijedlog Hrvatskog društva inžinira i arhitekta u Zagrebu nudio jednostavnije križanje, bez trga na tom mjestu. ${ }^{17}$ Najjužnija zemljišta uz Branimirovu ostala su dugo izvan dosega ambicioznijeg planiranja i tu su se s vremenom smjestila skladišta i tvornice. Najkvalitetnija gradnja, koja i danas svjedoči o industrijskoj prošlosti zemljišta uz prugu, jest tvornica Penkala (poslije »Nada Dimić«) na uglu Branimirove i novoosnovane Erdödyjeve ulice, za koju su 1909. godine Hönigsberg i Deutsch izradili prve nacrte. Današnji izgled zadobila je nakon 1919. kada ju je proširio i preoblikovao Rudolf Lubynski. ${ }^{18}$

5. Varijanta regulatorne osnove za istočni dio grada Milana Lenucija iz 1909. s malim trgom u produžetku Hatzove ulice (Državni arhiv u Zagrebu)

Milan Lenuci's 1909 variant of the regulatory plan for the eastern part of the city 
Lenucijeva je regulatorna osnova za dio grada istočno od Draškovićeve ulice iz 1905. godine važna jer je prostorno, prometno, a dijelom i sadržajno definirala prostor istočne ekstenzije Donjega grada kao dijagonalne magistrale $s$ trgovima, čija je integrativna funkcija spajanje centra grada s predgrađima.

Zvonimirova neće biti izvedena u potpunosti do Maksimirske aleje, već završava na cesti Svetice, ali se Šubićeva, pandan Višeslavovoj u simetričnom reguliranju sjeverne strane Krešimirova trga i jedna od bitnih veza ovog dijela grada s budućim velikim i brzim prometnicama (Držićeva, Most mladosti), 1909. godine trasira u punoj širini.

Lenuci je dao prednacrt istočnog dijela grada kao stambeno-poslovnog i ozelenjenog. Time će radnički i tvornički kvartovi, tj. periferna usitnjena gradnja, biti 1920-ih potisnuti dalje na istok (iza Kvaternikovog trga i u Maksimir) i na jugoistok (parcelacije naselja i gradske kuće na Kanalu), a Trnje će ostati sinonim divlje gradnje do nakon Drugoga svjetskog rata.

Iz Lenucijeve regulacije iščitavamo današnju os triju trgova, s obveznim drvoredima i parternim zelenilom, pa iako su mnoge ideje ostale nerealizirane, druge su realizirane i kvalitetnije nego ih je zamišljao.

\section{Međuratno razdoblje - realizacija središnjega istočnog dijela grada - identitet i prepoznatljivost}

U razdoblje nakon Prvoga svjetskog rata Zagreb je ušao bez generalne regulatorne osnove, pa su prve godine u regulatornom smislu bile pripremne. U Gradskom građevnom odsjeku izrađen je Nacrt Zagreba 1923. s elementima regulacije pod vodstvom inženjera Karla Vajde, kojim su obuhvaćeni dotadašnji parcijalni planovi za pojedine dijelove grada. ${ }^{19}$ Najprirodnije širenje grada prema jugu bilo je onemogućeno željezničkom prugom koja je i dalje prolazila u nivou ulica i kočila redoviti cestovni promet, a predjeli oko rijeke Save još nisu bili kanalizirani. Sjeverni obronci postupno su se regulirali i gradili kao ljetnikovačka stambena zona, sada mnogo gušće nego prije. Zapadni dio grada bio je stiješnjen prugom i relativno popunjen, pa je Gradska općina izgradnju usmjeravala prema istoku, nadovezujući se na zaključke urbanista prethodnog razdoblja. ${ }^{20}$

Modernizacija istoka nastavila se artikulirati i njime sad dominira Trg žrtava fašizma, tzv. Trg N. Na nacrtu grada iz 1923. godine to je pravilan kvadratni trg iz čija tri kuta, kao i sredinom dviju bočnih strana, izlaze jake komunikacije. Krešimirov trg prikazan je kao nešto veći pravokutni trg iz čija tri kuta i s dviju bočnih strana također izlaze komunikacije (ali ne toliko geometrijski pravilno), a na njegovoj sjevernoj strani na zemljištu do Zvonimirove planiran je veliki perivoj (čije je uređeno parterno zelenilo, kao i Trga $\mathrm{N}$ prikazano na Perspektivnoj panorami Zagreba 1926.). ${ }^{21}$

Na nacrtu grada iz 1923. godine po prvi je put prikazana već dijelom izgrađena Dijagonalna (Mislavova) ulica, trasirana kao pandan Ulici Račkoga; s kojom između Draškovićeve i

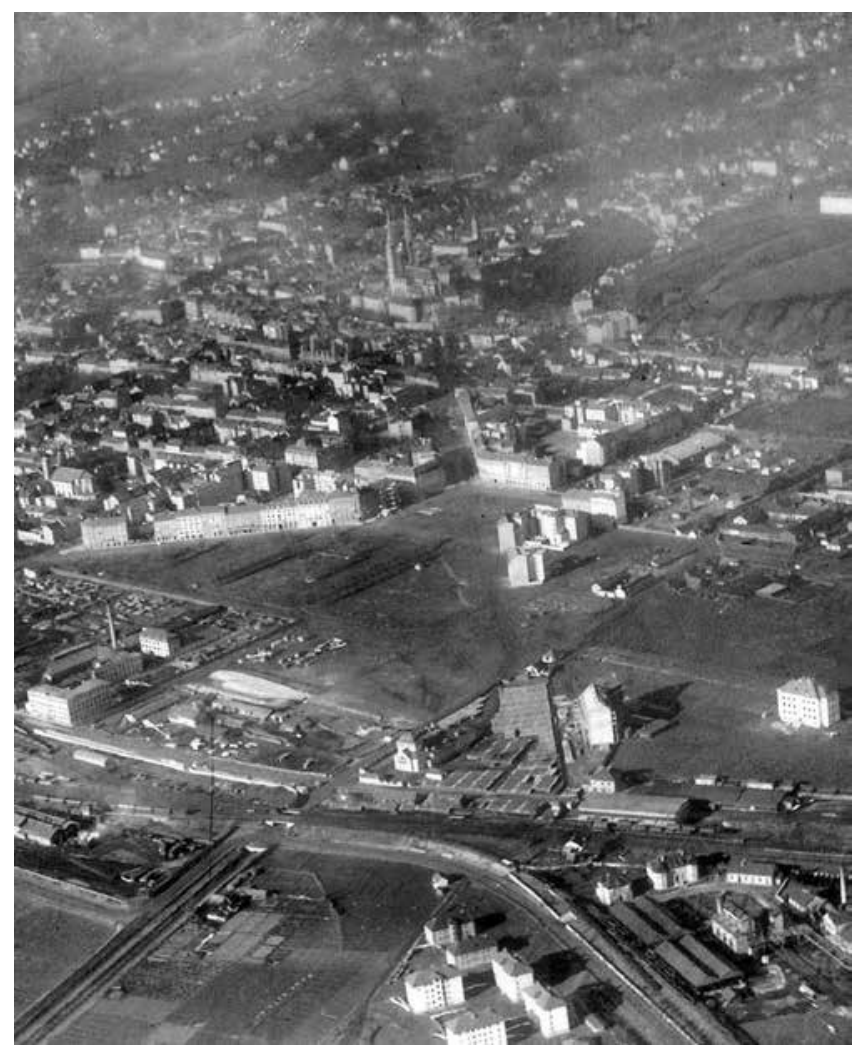

6. Pogled duž dijagonale JI - SZ trgova u nastajanju oko 1923. Lijevo dolje je Tvornica Penkala, a iznad nje izgrađena sjeverna fronta Mislavove ulice. U sredini dolje su Gradske kuće s malim stanovima na Kanalu južno od pruge. Na sjevernu stranu Trga žrtava fašizma još izravno izlazi Tomašićeva ulica, a na njezinoj su istočnoj strani smješteni izložbeni paviljoni Zagrebačkog zbora.

View from the south-eastern part of the city towards the Cathedral, around 1923. The Penkala Factory is at the bottom left, with the north side of Mislavova Street above it. Below to the right, there are the City Houses with small apartments at the Canal. Tomašićeva Street leads to the north side of the Square of the Victims of Fascism, and the exhibition pavilions of the Zagreb Fairgrounds are located on its east side.

Trga N sastavlja pravilni trapez. U cijelosti su već izgrađeni blokovi: Račkoga - Mutimirova - Trg N - Držislavova, te Držislavova - Draškovićeva - Mislavova - Trg N, a dobrim dijelom i jedan od najvećih blokova Račkoga - Smičiklasova - Martićeva - Tomašićeva - Trg N; tj. zapadna i sjeverna strana Trga žrtava fašizma. U potezu Višeslavove ulice prema Krešimirovu trgu gradilišta se tek počinju parcelirati.

U taj opsežni i geometrični nacrt grada uključene su mnoge pojedinačne regulacije cesta koje se intenzivno rade od 1919. godine. Od kontaktnih zona uklopljen je planirani proboj Vojnovićeve ulice, zadane vizurom pročelja crkve sv. Petra na sjevernoj strani Vlaške (1919.), ${ }^{22}$ zatim Regulatorna osnova Vlaške (1919.), Vončinine (1921.) i planirane Schlosserove stube prema Šalati (1922.). Na tom planu već prepoznajemo fizionomiju središta Zagreba.

Nakon Prvoga svjetskog rata Zagreb postaje jedno od važnijih gospodarskih središta, u kojem se razvijaju veletrgovina, industrija i bankarstvo, a očekuju se i važnija inozemna ulaganja. ${ }^{23} \mathrm{U}$ gospodarskom i arhitektonskom smislu najznačajniji događaj bila je gradnja Burze, na parceli broj jedan 


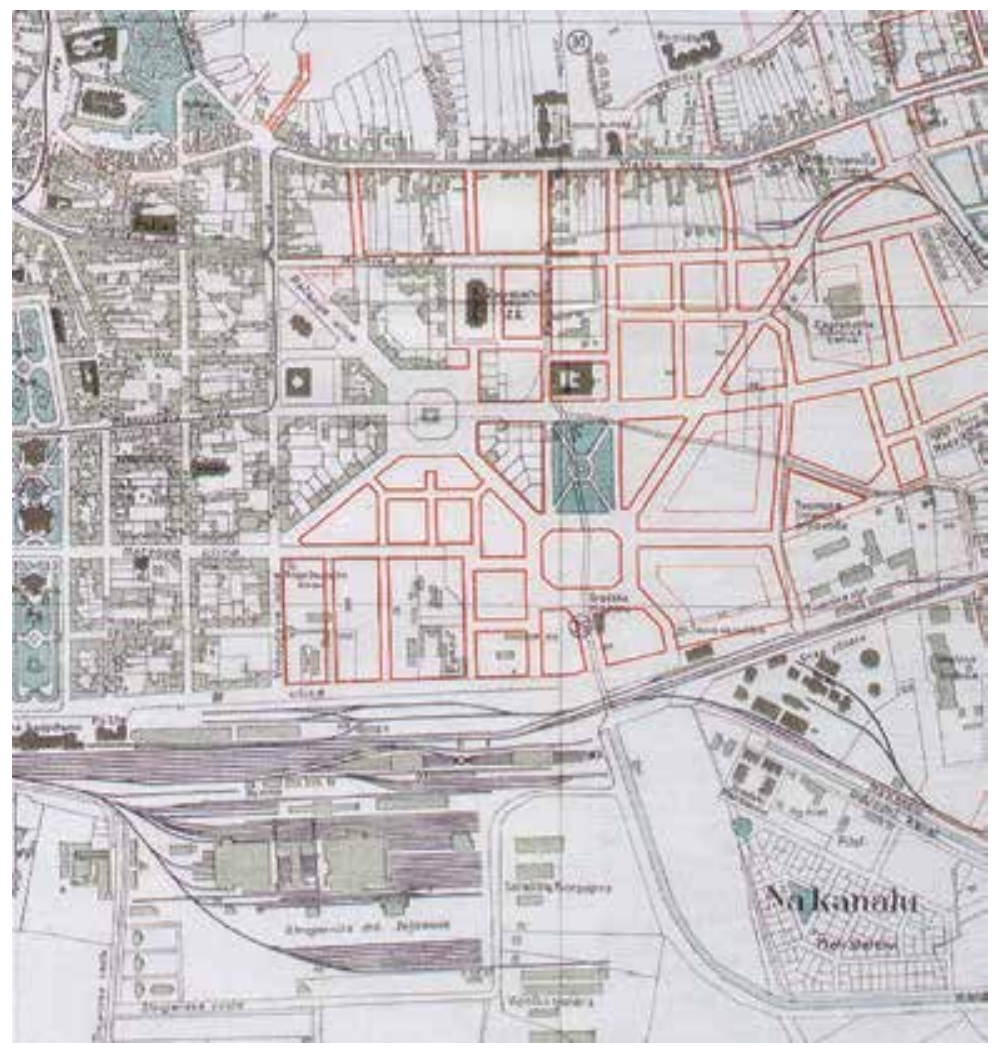

7. Nacrt grada Zagreba 1923. s elementima regulacije Karla Vajde, presudan za artikuliranje modernizacije gradskog istoka u međuratnom razdoblju, detalj (Muzej Grada Zagreba)

Zagreb City Plan from 1923 (segment), with elements of regulation by Karlo Vajda, was to become crucial for the more articulated modernization of the eastern part of the city velikoga novoga gradilišta istočno od Draškovićeve, ${ }^{24}$ za koju je bio organiziran uži arhitektonski natječaj (1920./21.). Ono što je nagrađeni rad Viktora Kovačića izdiglo nad konkurentima bio je urbani prizor koji je ponudio, a to je formiranje "vrata" u novi gradski predio. Tako je urbanistička zamisao zrcalnih kuća na početku Ulice Račkoga (Burze i budućega Inženjerskog doma) zadala ne samo ulaz u buduću četvrt financijskih i trgovačkih društava i ustanova, nego i ambicioznije oblikovanje samog Trga Burze (Trga hrvatskih velikana), prvog u nizu na dijagonalnoj osi.

Zgrada Burze jedno je od najznačajnijih djela međuratne hrvatske arhitekture, koja svojom mirnom, masivnom i otmjenom vanjštinom dominira trgom. Glavno je pročelje okrenuto Jurišićevoj, važnoj prometnoj žili kucavici, koja veže stariji centralni dio Zagreba s novim istočnim dijelom. ${ }^{25}$ Burzi je na Trgu Burze pandan Dom inžinjera koji je suzdržano, podređujući se Kovačićevoj viziji, projektirao Aladar Baranyai, čime je realizirana efektna simetrična vizura. ${ }^{26}$ Burza odmah postaje simbol novoga merkantilnog doba i oko nje nastaje četvrt monumentalnih zgrada u stilu klasičnog modernizma 1920-ih. Najveći investitori su novčarski zavodi i institucije, koji podižu svoja reprezentativna zdanja i stambene zgrade za svoje zaposlenike. ${ }^{27}$ Mnoga dionička društva - povezana ponajprije s drvnom i građevinskom, ali i kemijskom i tekstilnom industrijom te željeznicom također ulažu u vlastite stambene zgrade, ${ }^{28}$ a tu su i gradska općina i nadbiskupija.

Provode se postupne parcelacije zacrtanih blokova koji više nisu pravokutni, nego trokutasti i trapezni. Prometno i urbanistički rješavaju se mnoga križanja i detalji ugaonih

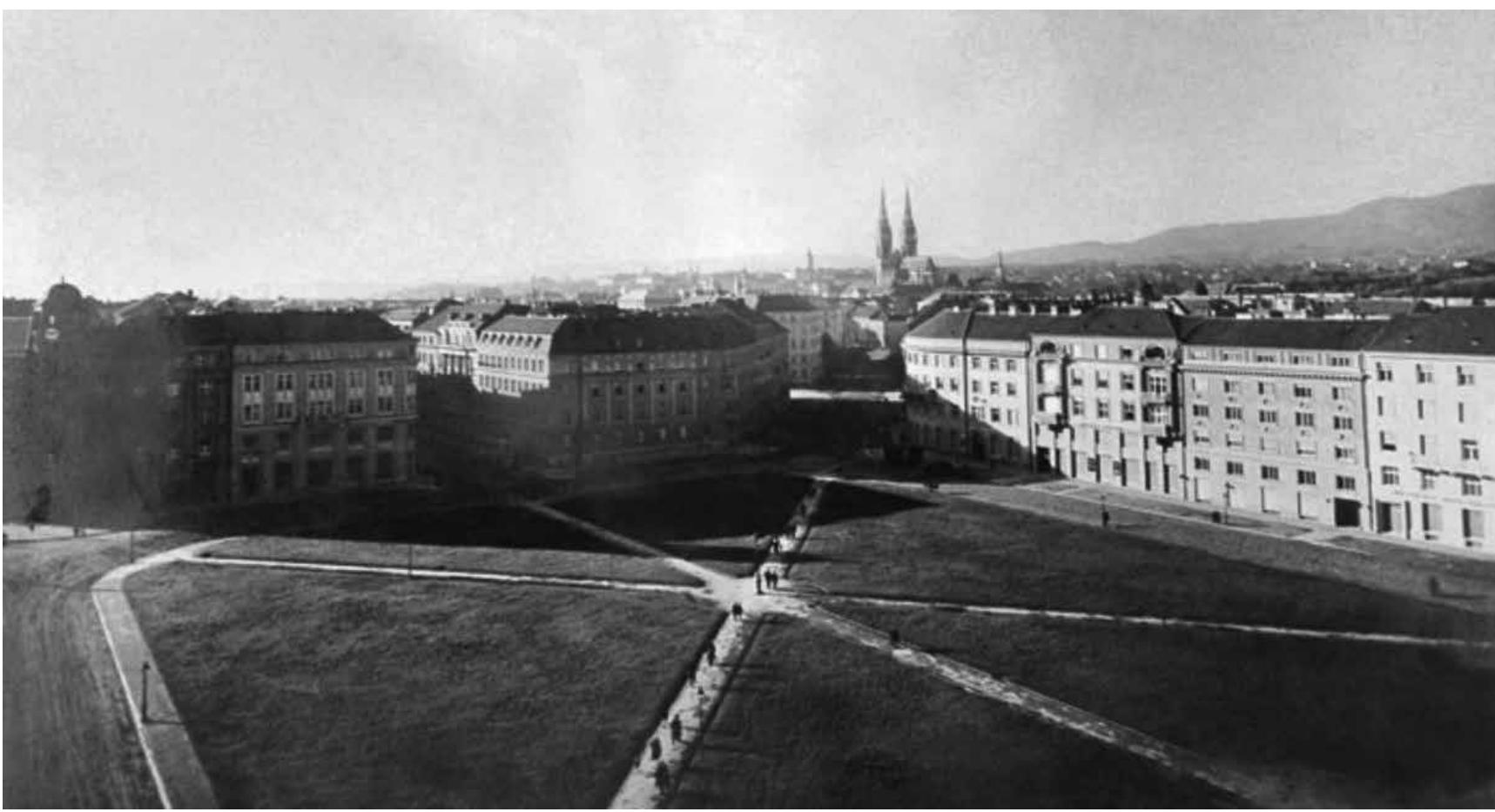

8. Pogled na sjevernu i zapadnu frontu Trga žrtava fašizma sa zrakasto organiziranim stazama kroz parterno zelenilo početkom 1920-ih West and north sides of the Square of the Victims of Fascism in the 1920s 


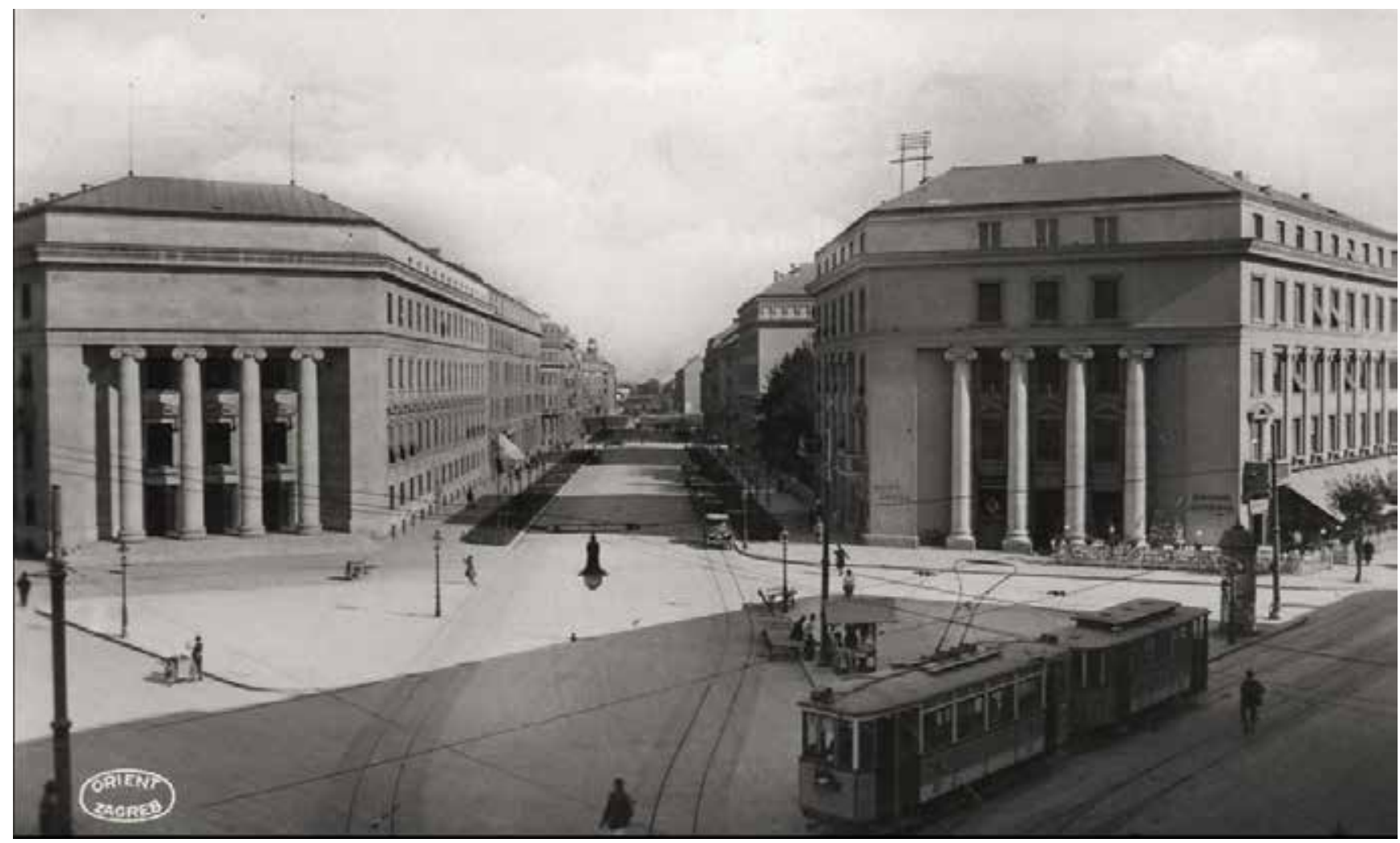

9. Simetričan ulaz u novu gradsku četvrt sa zrcalnim kućama, Burzom Viktora Kovačića i Inžinjerskim domom Aladara Baranyaia, te pogled niz os Račkoga - Višeslavova (Foto Orient Zagreb, početkom 1930-ih)

Twin buildings at the beginning of Račkoga Street: the Stock Exchange by Viktor Kovačić and the House of Engineers by Aladar Baranyai; with a view down the diagonal axis of Račkoga-Višeslavova streets in the early 1930s

parcela, blok po blok, kuća po kuća, kako se gradilo. Razvija se specifičan tip poslovno-stambenih zgrada, trokatnica i četverokatnica, s obveznim poslovnim polukatom i krovnom mansardom sa samačkim sobama. ${ }^{29} \mathrm{U}$ slučaju banaka ili tada raširenih »domova« raznih društava obvezne reprezentativne dvorane projektirane su u prizemlju ili u izdvojenome dvorišnom krilu. Privučeni stimulativnim olakšicama, privatnici također ulažu u novogradnje, pa nastaje pravi graditeljski boom koji kulminira 1925., a posebno u sezoni 1927./28. godine (kada je glavnica uložena u novogradnje donosila 20 posto ukamaćenja). ${ }^{30}$

\section{Karakteristike europske arhitekture skladno prevedene u zagrebačke razmjere}

Stilski jedinstvenu i simultanu realizaciju ovog dijela grada omogućila je generacija hrvatskih arhitekata školovanih diljem Srednje Europe u vrijeme dok Zagreb još nije imao Tehnički fakultet, a među prvima: Viktor Kovačić, Hugo Ehrlich, Janko Holjac, Edo Šen, Juraj Denzler, Rudolf Lubynski, Aladar Baranyai, Vjekoslav Bastl, Dionis Sunko, Ignjat Fischer, Lav Kalda i Amadeo Carnelutti.

Dionis Sunko specijalizirao se za gradnju financijskih ustanova (ne samo u Zagrebu nego i Beogradu, Sarajevu i drugdje) koje su raščlambom već bliske art décou. Česti svoj motiv uvučenog ugla oblikovanog kao valjak koji završava u kupoli, upotrijebio je na zgradi Osiguravajuće zadruge Triglav na Trgu žrtava fašizma 14 - Mislavova 17 (1923.). Srodna joj je uglovnica Hrvatske poljodjelske banke, Martićeva 6 - Smičiklasova 17 (1926.), koju je odrezanom linijom u prizemlju uvukao od gabaritne linije, a to nadoknadio dominirajućim polukružnim istakom koji završava u dvokatnoj uskoj kupoli. Kao kod Kovačićeve Burze ili Ehrlichove Slavenske banke, koncept glavne dvorane riješen je smještajem između bočnih krila i zenitalnim osvjetljenjem. Za Osiguravajuće društvo Dunav preoblikovao je i susjednu zgradu Martićeva 8, koja se tako stilski povezala s njegovom uglovnicom.

Nasuprotnu uglovnicu Martićeva 4 (1922. - 1927.), kao i Dom inžinjera (Trg hrvatskih velikana 6, 1927.) arhitekt Aladar Baranyai projektirao je u subordinaciji prema Viktoru Kovačiću i Dionisu Sunku. ${ }^{31} \mathrm{U}$ oba slučaja referirao se na tuđe rješenje s kojim stvara uravnotežen urbani prizor simetričnih vrata, u Račkoga i u Smičiklasovoj. Originalnost vlastitog repertoara pokazao je definirajući izgled sjevernoj i istočnoj strani Trga žrtava fašizma, na kojem je od 1924. do 1929. podigao trgovačko-stambene zgrade kbr. 2, 4, 5, 6, 9, kao i mnoge kuće u okolnim ulicama: Mislavova 7 (1923.), Dukljaninova 3 (1924.), Domagojeva 6 (1927.), Zvonimirova 4 i 6 (1924. i 1928.) te Višeslavova 2 i 14 (obje 1927./28.). Na uglovnici Hrvatske sveopće prometne banke Martićeva - Tomašićeva 2 (1922. - 1926.) poslužio se projektom koji je godinu ranije ponudio na pozivnom natječaju za Burzu. ${ }^{32}$ 


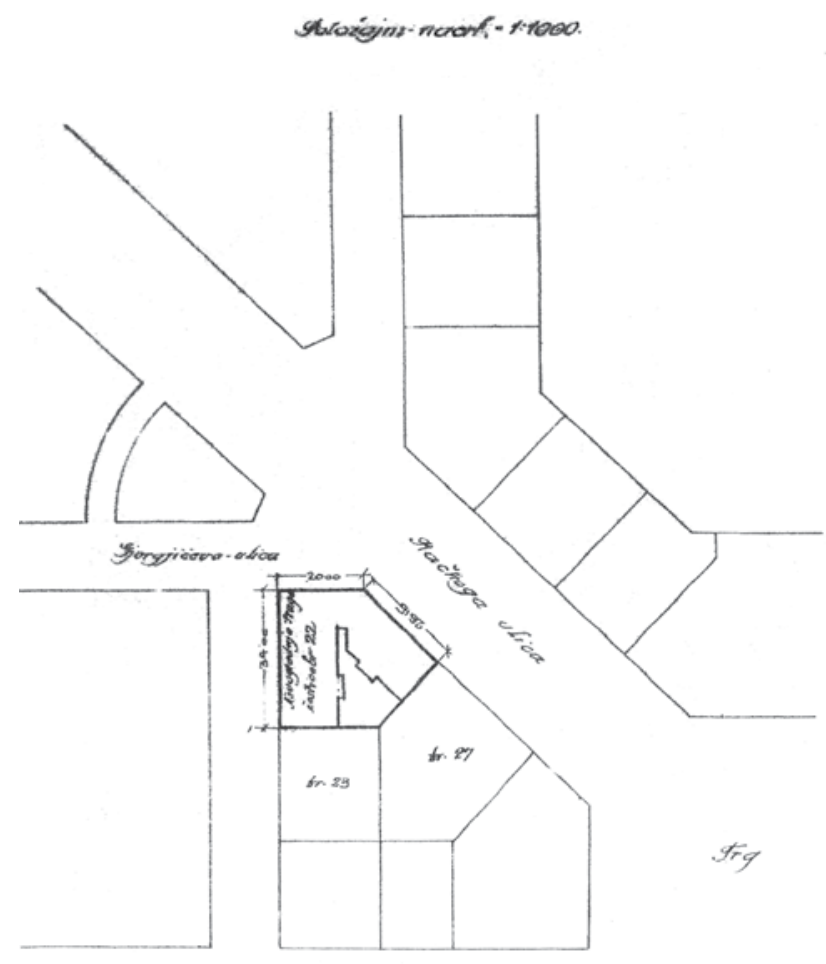

10. Križanje i situacija uglovnice Pruga d. d., Račkoga 8, Hugo Ehrlich, 1920. (Državni arhiv u Zagrebu)

Location of the corner building of the Railways company at Rackoga Street 8, Hugo Ehrlich, 1920

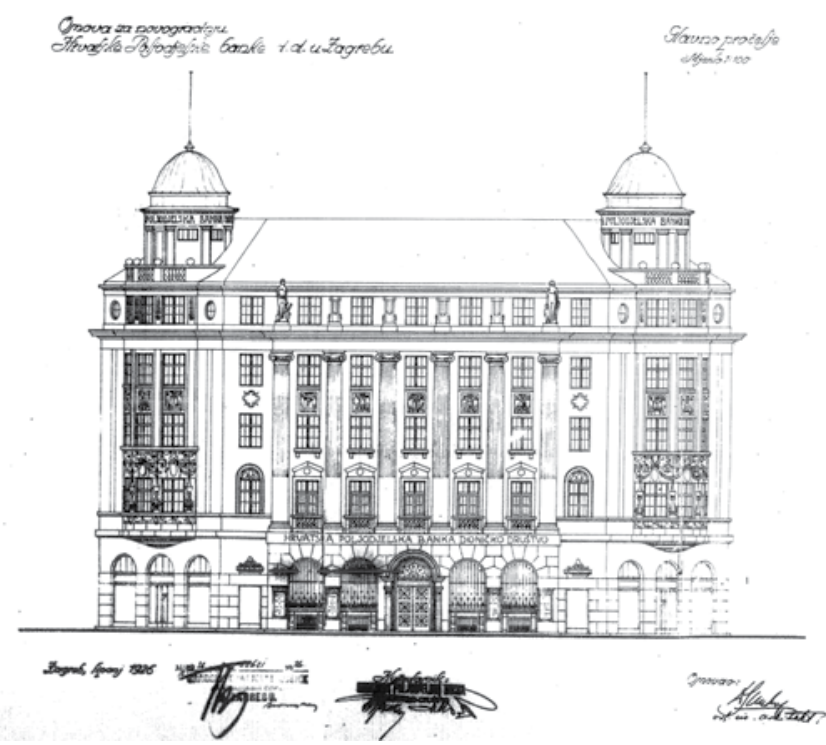

12. Stambeno-poslovna zgrada Hrvatske poljodjelske banke dd, Martićeva 6 - Smičiklasova, Dionis Sunko, 1926., glavno pročelje (Državni arhiv u Zagrebu)

Office and apartment building of the Croatian Agricultural Bank on the corner of Martićeva 6 and Smičiklasova, Dionis Sunko, 1926, main façade

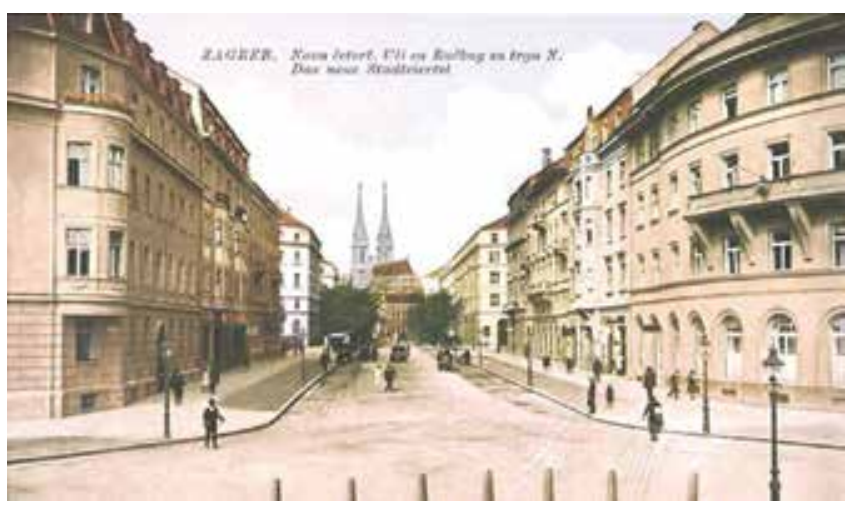

11. Račkoga ulica - kičma nove gradske četvrti (razglednica) Rackkoga Street - the backbone of the new city district

Tomašićeva ulica primjer je kontrasta ekonomske snage elegantne arhitekture 1920-ih na zapadnoj i serijski uniformne kasnih 1930-ih na istočnoj strani. Svojim epskim programom na zapadnoj strani ističe se poslovno-stambena kuća Glück ovlaštenih graditelja Pollak i Bornstein (kbr. 10, 1922.) ${ }^{33}$ koji su do maksimuma iskoristili parcelu u dvorištu sagradivši elegantno prizemno i dvokatno krilo, s verandama i garažom. Taj je veliki gradski blok umjesto zatvorenoga unutarnjeg

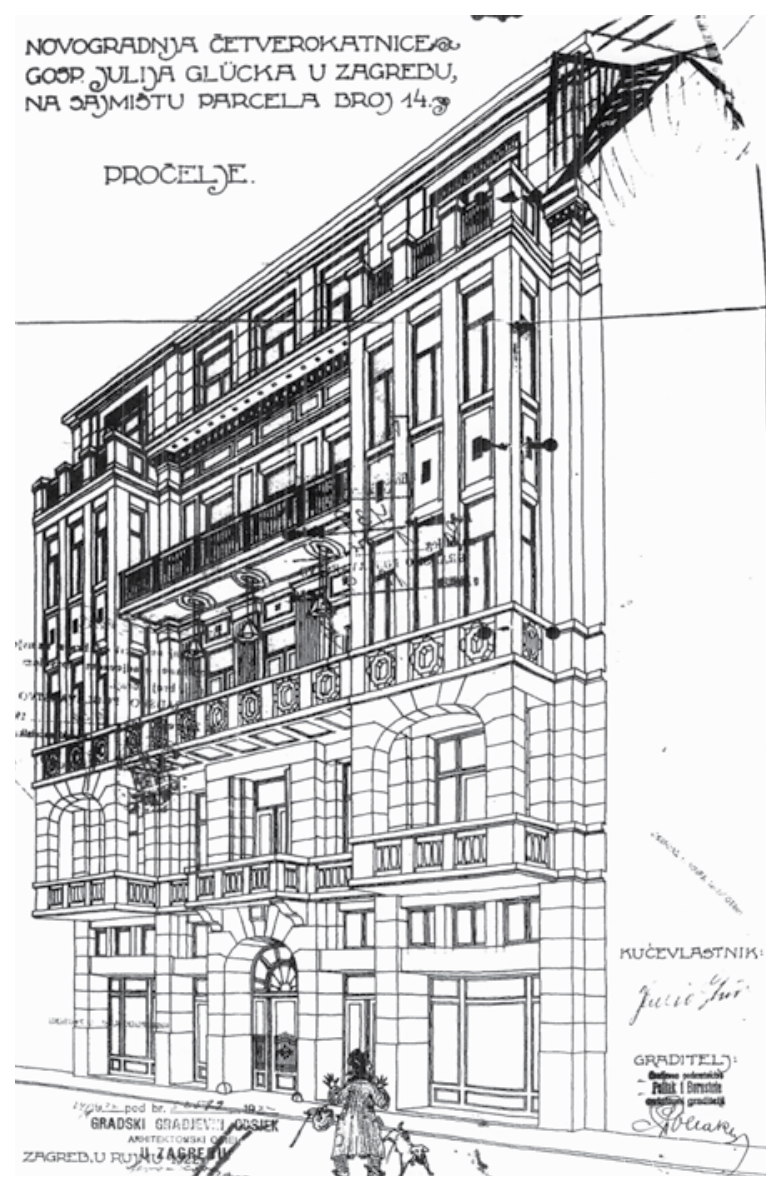

13. Trgovačko-stambena kuća Glück, Tomašićeva 10, Pollak i Bornstein, 1922. pročelje (Državni arhiv u Zagrebu)

Commercial and apartment building Glück, Tomašićeva 10, Pollak and Bornstein, 1922, front façade 


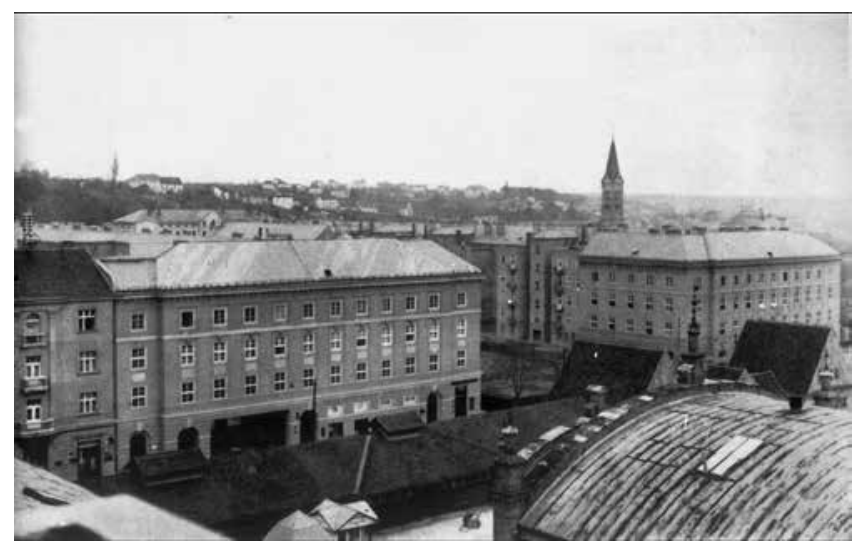

14. Pogled s južne strane Martićeve na gradnju monumentalnog stambenog bloka Nadarbine nadbiskupije zagrebačke, Vlaška - Martićeva - Bauerova - Ratkajev prolaz, Hugo Ehrlich, 1926. - 1930. U prvom planu je krov Jašione, tj. izložbeni paviljoni Zagrebačkog zbora. Construction of the monumental apartment block of the Archdiocesan Endowment, Vlaška - Martićeva - Bauerova - Ratkajev Passage, view from the south side of Martićeva Street, Hugo Ehrlich, 1926-1930

dvorišta imao zelenilo i dijagonalnu pješačku stazu (SZ - JI), koji su ekspanzijom okolne gradnje dokinuti 1930-ih.

Arhitekt čiji je rukopis bitno odredio izgled četvrti jest Hugo Ehrlich, dovršitelj Loosove vile Karme. Nakon što je godinu od početka gradnje Burze Viktor Kovačić umro, kao pouzdani predratni njegov partner, Ehrlich dovršava vanjštinu, naglasivši poslovni karakter zgrade. Dotad je već s nekoliko vlastitih poslovno-stambenih trokatnica u blizini Burze, gabaritom, elegancijom i solidnošću izvedbe, najavio svoj opus. Jedna od prvih je zgrada Pruga d. d., na peterokutnoj parceli, koja je zadala ugao produžene Đorđićeve ulice i Račkoga 8 (1920. - 1922.) u karakterističnom stilu klasičnog modernizma 1920-ih. Gradio je i nasuprotnu kuću Tekstil d. d., Račkoga 9 (1921.), te u vizuri Draškovićeve prema sjeveru nezaobilaznu uglovnicu Slavenske banke i Schlosserove stube (1921.-24.), koji su zadali novo mjerilo u kontekstu stare tradicionalne gradnje. ${ }^{34} \mathrm{Na}$ sjevernoj strani Trga Burze realizirat će uglovnicu Braće Janeković (poslije Jadransko osiguravajuće d. d., danas Općina Medveščak) za koju je dobio nagradu na užem natječaju (Draškovićeva 15 - Martićeva 1-3,1928.). Pročelja raščlanjena samo vodoravnim perforacijama i završnim vijencem, s udubljenom nišom u visini prvoga i drugog kata, pokazuju kasniji smjer prema modernoj arhitekturi. Napokon, Ehrlich je ostvario jedan od najvećih građevinskih poduhvata 1920-ih, u četvrti i Zagrebu - monumentalni stambeni superblok najamnih stambenih zgrada Nadarbine nadbiskupije zagrebačke (25 zgrada, oko 180 stanova, 17 lokala na $7000 \mathrm{~m}^{2}$ ). Kompleks je projektiran s unutarnjim dvorištima i prolazom, na strani Vlaške i Martićeve s uvučenim dijelom za smještaj javnog zelenila (Vlaška - Bauerova - Martićeva, 1926. - 1930.).

Edo Šen (uz Ehrlicha sad već profesor netom osnovanoga Tehničkog fakulteta) je s Jurjem Denzlerom na užem natječaju dobio gradnju uglovnice Direkcije šuma (danas Privredna banka Zagreb, Bornina - Mislavova 2-4, 1923. - 1926.). Oštri je kut kuće izbjegnut povlačenjem od ugla i formiranjem

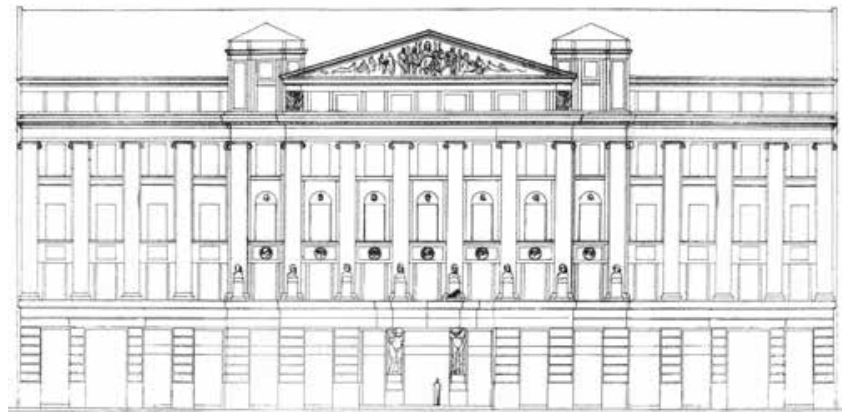

15. Dom Hrvatskog Radiše, Mislavova 6-10 / Bornina 3-5, Vjekoslav Bastl, 1924. - 1929., pročelje (Državni arhiv u Zagrebu)

Croatian Workers' House, Mislavova 6-10 and Bornina 3-5, Vjekoslav Bastl, 1924-1929, front façade

širega spojnog pročelja s balkonima na prvom katu (što na bočnim stranama, prema Borninoj i Mislavovoj, nije bilo moguće). ${ }^{35}$ Susjedni Dom Hrvatskog radiše, koji se također proteže kroz blok i izbija na dvije ulice (Mislavova 6-8-10 - Bornina 3-5, 1924. - 1929.), s karakterističnim zabatom nad pročeljem i plitkim jonskim pilastrima tipičnima za zagrebačku arhitekturu ovog dijela grada, projektirao je Vjekoslav Bastl. Već je prije podigao dvije kuće u Draškovićevoj 25 i 27, potom uglovnicu Više komercijalne škole (također Hrvatski Radiša) u Zvonimirovoj 8 (1928.), a preoblikovat će i crkvu sv. Petra u Vlaškoj (1930.).

Osim tvornice Penkala, uglovnice Trg N - Zvonimirova (1922. - 1924.) i preoblikovanog pročelja u Držislavovoj 8 (1927.), Lubinsky je u Smičiklasovoj 19 (1925. - 1926.) na uglu s Patačićkinom sagradio kuću za sebe i svoju obitelj, jednostavnih ploha sa simetrično smještenim dvokatnim erkerom i karakterističnim trodijelnim kvadratnim prozorima. Lav Kalda autor je obiju uglovnica na zapadnoj strani Trga žrtava fašizma i Držislavove; jedne zatvorenog pročelja, a druge - kuće Ullmann - izuzetno rastvorene art déco fasade s visokim prizemljem i međukatom, od katova odvojenih jakim vijencem (Narodne novine, Trg žrtava fašizma 12, 1924.).

Kao što su Baranyai i Sunko zadali ton dijelu Martićeve i Trga žrtava fašizma, tako su ambijent Višeslavove ulice odredile elegantne palače tandema Cernjak i Neumann, koji visinom vijenaca i prozora te kosinom krova usklađuju međusobno svoja pročelja u harmoničnu cjelinu (kbr. 3, 5, 7 i 8, većina 1927.). Braća Carnelutti prisutna su u izgradnji četvrti od ulice Račkoga (kbr. 7, 1925.) do Krešimirova trga (Višeslavova 13, 1931.), gradeći tijekom cijelog razdoblja po svojim i po projektima drugih arhitekata, baš kao i Aranjoš i Popović. Freudenreich i Deutsch realizirali su u ovom dijelu grada svojih sedam, Ivo Marčelja tri, a arhitekt starije generacije Ćiril Metod Iveković jednu građevinu (Račkoga 11, 1922.). Nekoliko kuća s malim stanovima sagradila je Gradska općina, bitno više kvalitete negoli na zemljištima na istoku grada i južno od pruge, poput Tomašićeve 12 (Harold Bilinić, Otto Goldscheider, Ivan Zemljak, Josip Gaupp, 1926.) i Švearove 5-7 (Karlo Vajda, 1927.). 


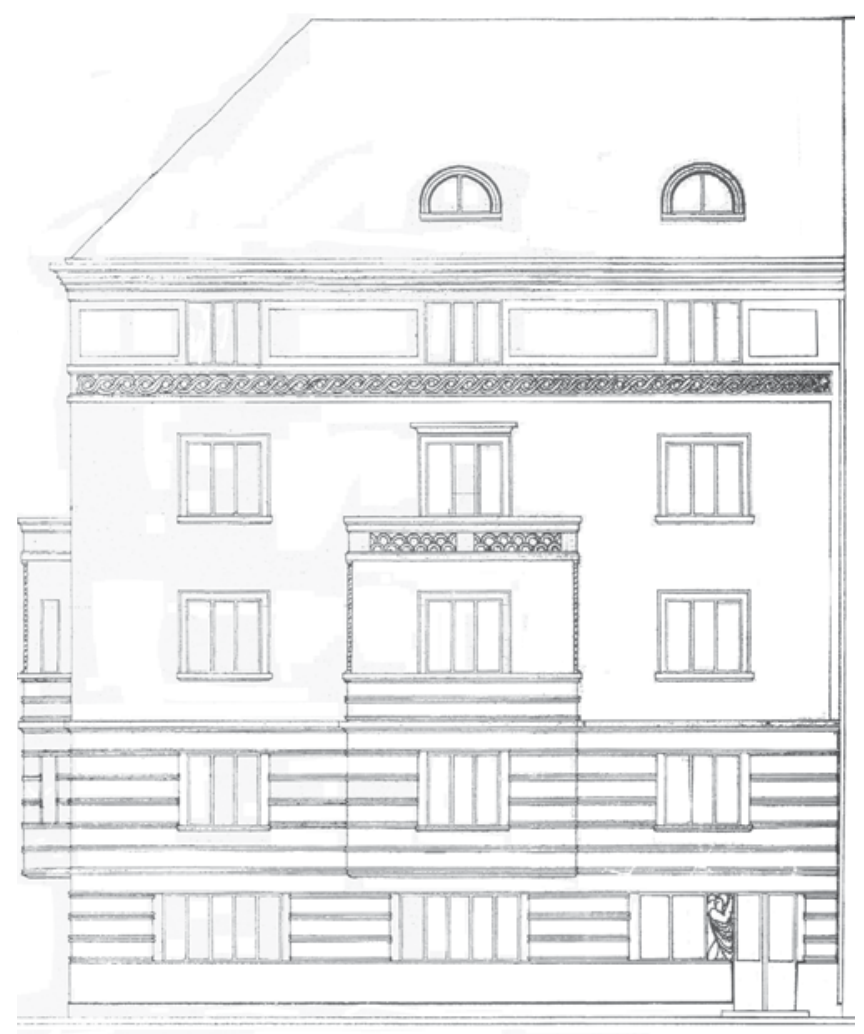

16. Kuća Lubynski, Smičiklasova 19, 1925. - 1926., pročelje (Državni arhiv u Zagrebu)

Lubynski house, Smičiklasova 19, 1925-1926, front façade

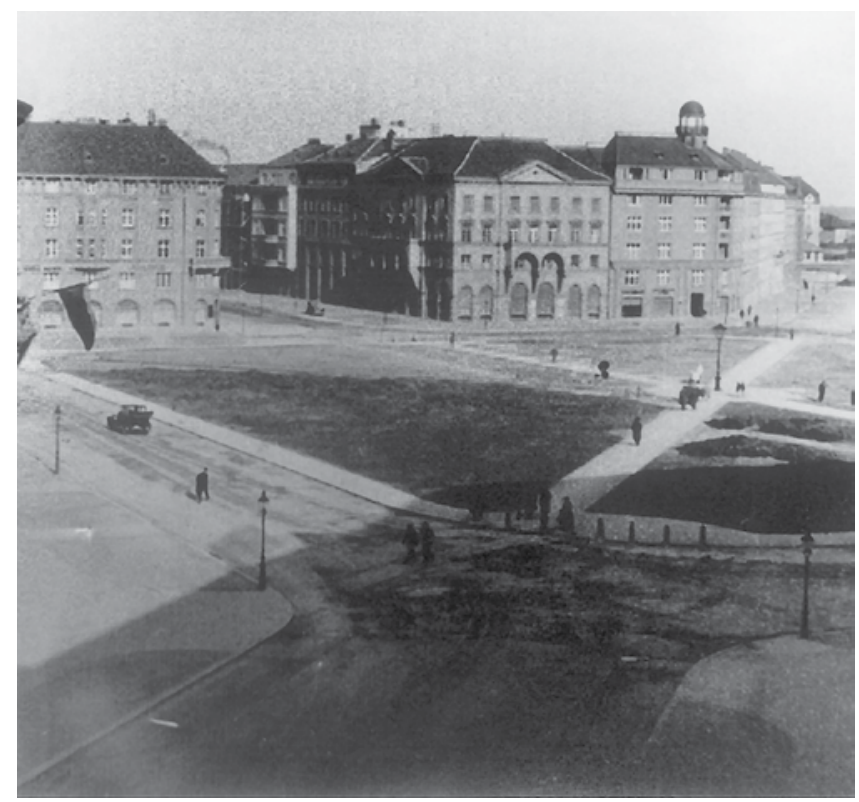

17. Pogled na istočnu stranu Trga žrtava fašizma s uglovnicama Rudolfa Lubynskog i Ignjata Fischera prema Zvonimirovoj te prema Višeslavovoj ulici s uglovnicom Aladara Baranyaia 1920-ih

East side of the Square of the Victims of Fascism with corner buildings designed by Rudolf Lubynski, Ignjat Fischer (towards Zvonimirova Street) and Aladar Baranyai (towards Višeslavova Street) in the 1920s
Promjene u oblikovanju najavit će velika uglovnica Glavne bratimske blagajne za osiguranje rudarskih radnika Stjepana Gomboša: kaskadno riješenog ugla, bez kupola i zabata nadomak Trga N (Mislavova 18-20 - Križanićeva 1 - Domagojeva, 1928./29.). Zapadna strana Trga Burze (Trg hrvatskih velikana), na strani Draškovićeve ulice, istodobno dobiva masivnu uglovnicu Bele Auera podignutu na načelima arhitekture funkcionalizma (Trg hrvatskih velikana 2, 1929.), trend potvrđen ugrađenom stambenom zgradom Pavla Deutscha do nje (Trg hrvatskih velikana 4, 1931.). Time je arhitektonski fond od šest kuća ovoga nevelikog trga-raskrižja, u cijelosti građenog između 1923. i 1931. godine, bio zaključen.

\section{Nov arhitektonski rječnik i urbana pravila}

Shvaćanje arhitekture i njezinih zadataka iz temelja se mijenja potkraj 1920-ih godina, te će homogena rješenja, koja su kronološki od Trga Burze prema Krešimirovu trgu gradila ovaj prostor, zamijeniti hibridnija rješenja 1930-ih.

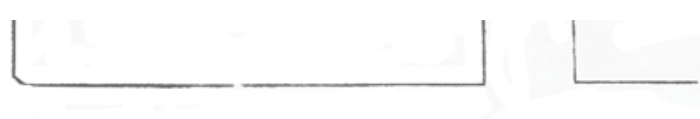

BOS̆KOVIĆEVA UL.

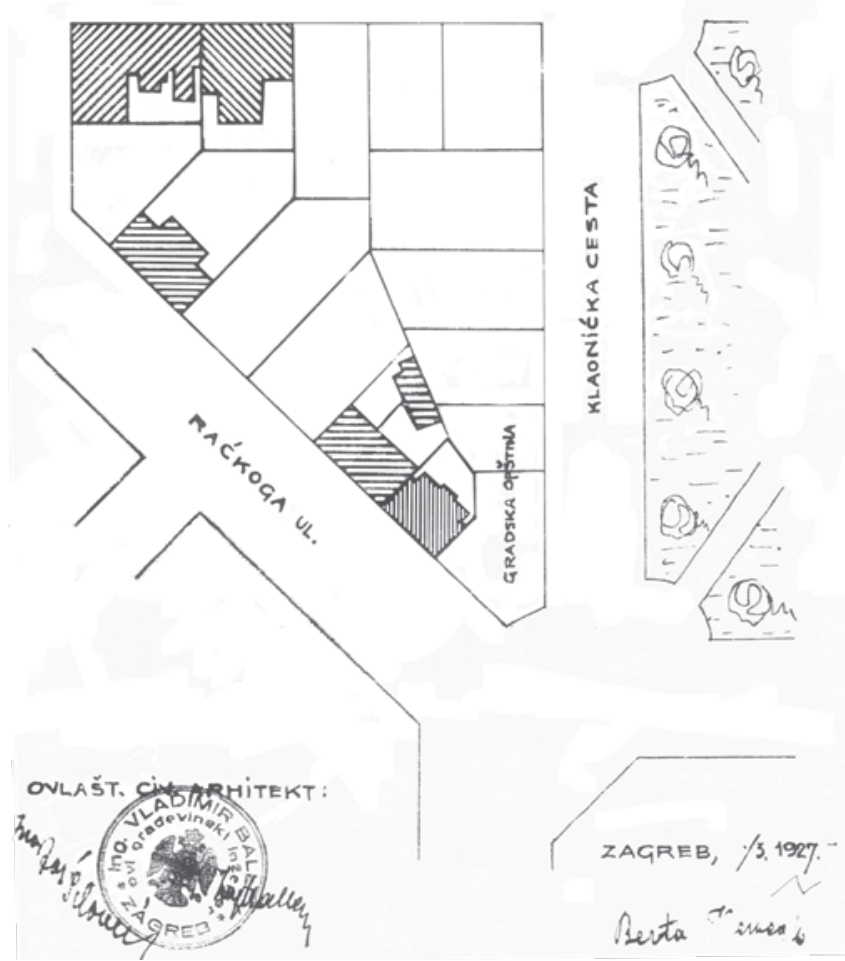

18. Parcelacija prvog bloka uz Višeslavovu ulicu (produžena Račkoga) s perivojem na istočnoj strani uz Bauerovu (Klaoničku), između Zvonimirove (produžena Boškovićeva) i Krešimirovog trga, 1927. (Državni arhiv u Zagrebu)

Allotment plan of the first block to be built along Višeslavova Street (here called "extended Račkoga") with the park on the east side, along Bauerova Street between Zvonimirova Street (here "Boškovićeva") and Krešimir Square, 1927 


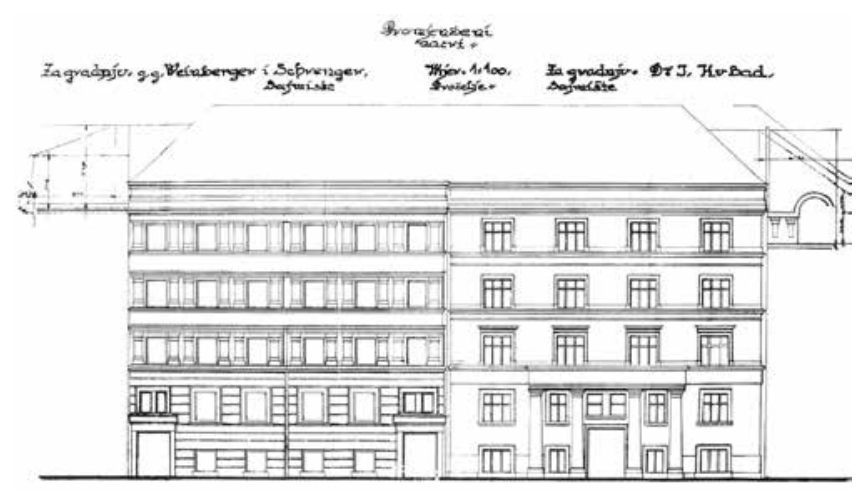

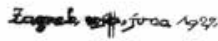

19. Zajednički projektirana pročelja u Višeslavovoj ulici zrcalnih zgrada kbr. 3 i 5 te kbr. 7, Cernjak i Neumann, 1927. (Državni arhiv u Zagrebu)

Jointly designed front façades in Višeslavova Street: twin buildings 3 and 5, and 7, Cernjak and Neumann, 1927

Pojedinačni arhitektonski zadatci okrupnjuju i na početku 1930-ih traže se jedinstvena rješenja za nekoliko blokova. Okidač je bio Ehrlichov stambeni kompleks između Vlaške i Martićeve, koji je predstavio mogućnosti takvoga cjelovitijeg pristupa ${ }^{36}$ Nakon što su tri strane Trga $\mathrm{N}$ popunjavana pojedinačnim kućama 1920-ih, stambenom zgradom JAZU (kasniji Studentski dom, kbr. 10) jedinstveno se rješava njegova južna strana. Za akademijinu stambenu zgradu 1930. godine bio je raspisan uži natječaj na kojem je prvu nagradu i izvedbu dobilo rješenje Ede Šena - široka zgrada suzdržane raščlambe pročelja, sa središnjim prolazom prema unutarnjem dvorištu s bazenčićem (1933.). ${ }^{37}$ Južniji veliki blok Križanićeva - Bornina osigurala je Banska uprava za smještaj Državne srednje škole. Monumentalan sklop srednjih škola Egona Steinmanna u Križanićevoj ulici (1930. - 1932.), koji je ujedno postao najveća građevina ovoga gradskog područja, amalgam je funkcionalne moderne arhitekture i novih pedagoških nastojanja.

Tek kada su problemi u fragmentarnoj izgradnji, prometu i higijeni grada postali nesavladivi, pristupilo se 1930. godine organiziranju međunarodnog natječaja za generalnu regulatornu osnovu grada. Rezultati će poslužiti pri izradi Generalnog regulacionog plana za grad Zagreb završenog 1936. godine (potvrđenog 1938.) kojim se funkcije rada, stanovanja, odmora i prometa, koji ih međusobno povezuje, osiguravaju zoniranjem i spajanjem u jedinstveni organizam, tzv. funkcionalni grad. ${ }^{38}$ Urbanisti zaposleni na izradi generalne regulatorne osnove bavili su se modernizacijom najužega gradskog središta te planiranjem Trnja, a za to je vrijeme područje oko Trga žrtava fašizma već postalo samoproglašeni »Novi Zagreb «. ${ }^{39}$

Reprezentativan sklop srednjih škola u Križanićevoj, dijelom izgrađeno veliko zdanje Hrvatskog radiše u Zvonimirovoj (na mjestu prije zamišljenog perivoja sjeverno od Krešimirova trga), gradski uredi interpolirani u unutrašnje dvorište bloka Smičiklasova - Martićeva, daljnja parcelacija dijela zemljišta Zagrebačkog zbora u Martićevoj, izgradnja koja ne ide

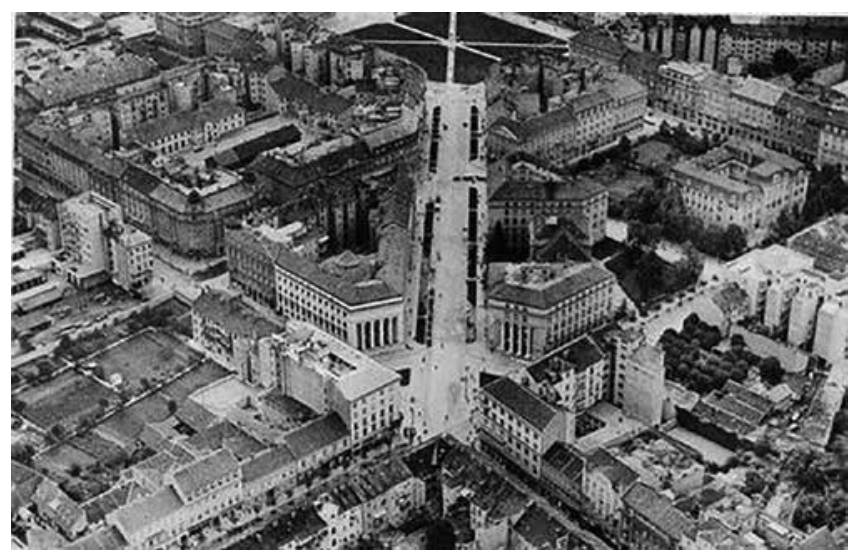

20. Izgrađen Trg Burze (tada Washingtonov trg), Griesbach i Knaus, Aeroklub Zagreb, oko 1935.

Aerial view of the Stock Exchange Square after the completion of the buildings, around 1935

južnije od Solovljeve (Bornine), osim uza zapadnu stranu Krešimirova trga (npr. Poštanski dom, kasniji "Kulušič, Hrvojeva 6, S. Šimunić - R. Krema, 1930.) itd. - prikazani su na Nacrtima grada Zagreba iz 1932. i $1934-35 .{ }^{40}$ Najveća razlika među njima sada je regulirani Trg žrtava fašizma.

Odsjek za regulaciju grada izradio je Osnovu za uređenje Trga kralja Petra (Trga žrtava fašizma) 1932., ${ }^{41}$ u kojem je istaknuta važnost glavnih prometnica Račkoga, Beogradske (Višeslavove) i Zvonimirove, koje rube dvostruki drvoredi, za razliku od jednostrukih uz Radišinu (Mislavovu) i Boškovićevu (Držislavovu). Trgom dominira prometni kružni tok, kojim je parterno zelenilo podijeljeno na veći središnji dio i disperzirane rubne dijelove uz okolne kuće. Zadatak da se u sredinu trga smjesti spomenik kralju Petru I. preveden je u ideju o izložbenom paviljonu. Jedna od urbanistički i simbolički najvažnijih građevina u ovom dijelu grada - Dom likovnih umjetnika kipara Ivana Meštrovića s arhitektima suradnicima (1934. - 1938.) - zadanoj je osi triju trgova i cijeloj gradskoj četvrti dodao snažnu novu dinamiku, izgledom i funkcijom. Okrugli paviljon onaj je važan reper koji se ističe u simetričnom pogledu od Burze niz Ulicu Račkoga, akcentuira središte Trga žrtava fašizma i ravnopravno se postavlja prema okolnim blokovima kuća i ulicama koje se od njega zrakasto šire. Drago Ibler je 1925. godine o trgu N pisao da je »u odnosu na visinu kućnih stijenki prevelik (...) i sa svih strana otvoren vjetru «. ${ }^{42}$ Sada je Dom likovnih umjetnika, zahvaljujući ravnoteži prema velikoj zelenoj površini na kojoj se smjestio, iskoristio šansu efektne prezentacije i stekao status najvažnijega arhitektonskog spomenika svog doba. ${ }^{43}$

Jedna od manjih regulacija koja posredno dovodi do bitnih promjena tiče se načina izgradnje Vlaške ulice glede visina $1931{ }^{44}$ godine. Nakon izgradnje Nadarbine tu se preporučuje graditi trokatnice i četverokatnice, što su objeručke prihvatili promotori moderne funkcionalne arhitekture Drago Ibler (Vlaška 60, 1931.) i Zlatko Neumann (Vlaška 69, 1935.), a slijedili su ih i drugi. Mogućnosti drukčijeg iskorištavanja parcele i njezina unutarnjeg dvorišta (smještajem radionica, 


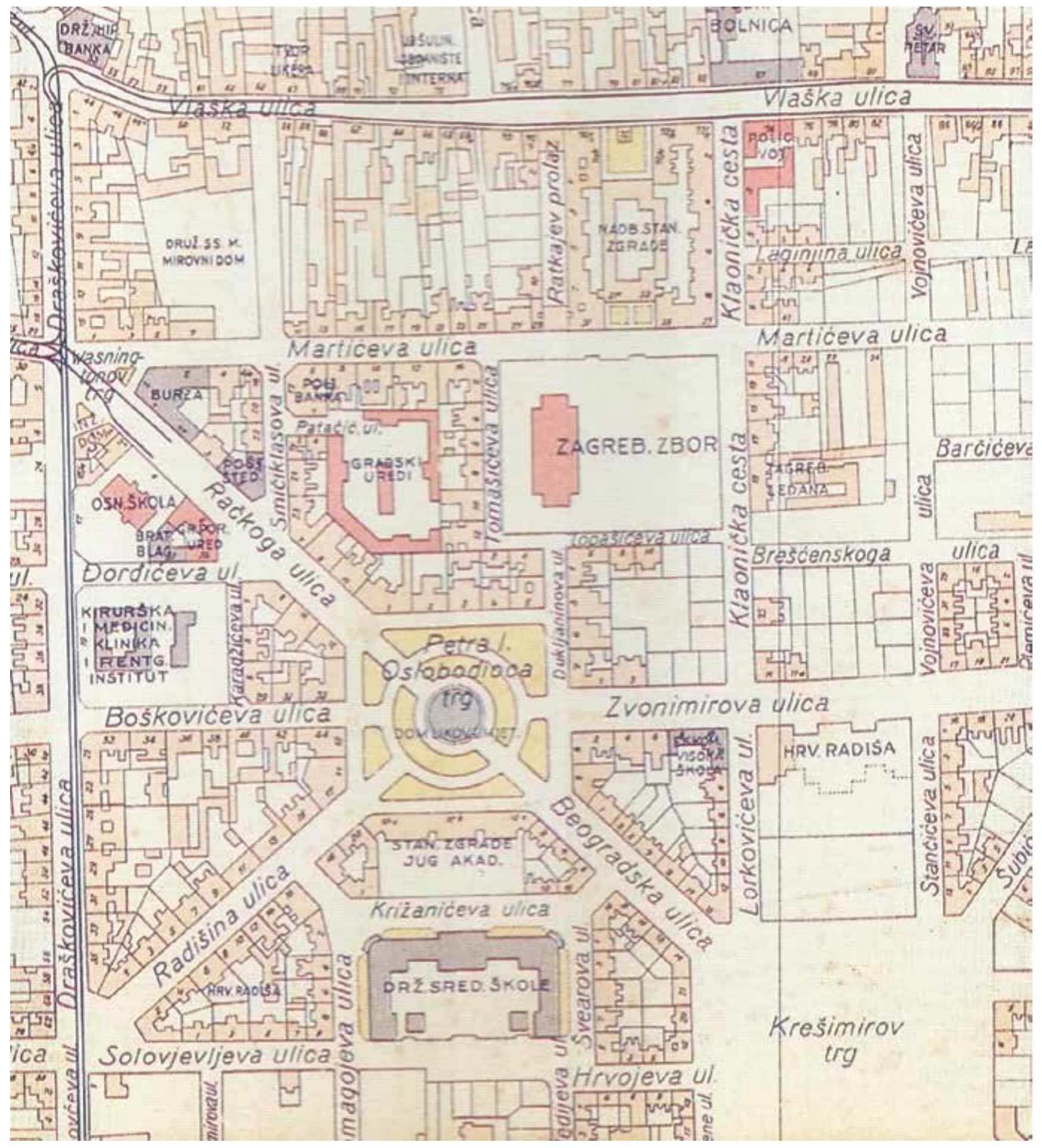

21. Nacrt grada Zagreba 1934. - 1935. Gradskog mjerničkog odsjeka u koji je uklopljena Osnova za uređenje Trga kralja Petra (Trga žrtava fašizma) iz 1932., s ucrtanim važnijim zgradama, detalj (Državna geodetska uprava)

Zagreb City Plan made by the City Surveying Department in 1934-1935 which included 1932 plan for the King Peter Square (Square of the Victims of Fascism), detail

ali i ostavljanjem slobodnoga javnog prolaza), predstavio je Ibler kućama Wellisch na zajedničkoj parceli - Vlaška 60 i Martićeva 13 - s jednakovrijednim dvorišnim i uličnim pročeljima (1930./31.). Trgovačka prizemlja podignuta na stupove, trake kontinuiranih prozora na glatkim pročeljima, važnost insolacije i stoga projektiranje lođa, velikih prozora i krovnih terasa, najavljeni su upravo avangardnom kućom Wellisch $\mathrm{u}$
Martićevoj ${ }^{45}$ kojom je ideja interpolacije kao ujednačavanja prostornih odnosa unutar postojećeg tkiva dokinuta.

Krešimirov trg bio je planiran kao ishodište prepoznatljive dijagonalne strukture istočnog dijela grada. Pozicija na raskrižju karakterističnih radijalnih ulica te u osi prijelaza željezničke pruge (Držićeva avenija) uvjetovala je karakter 


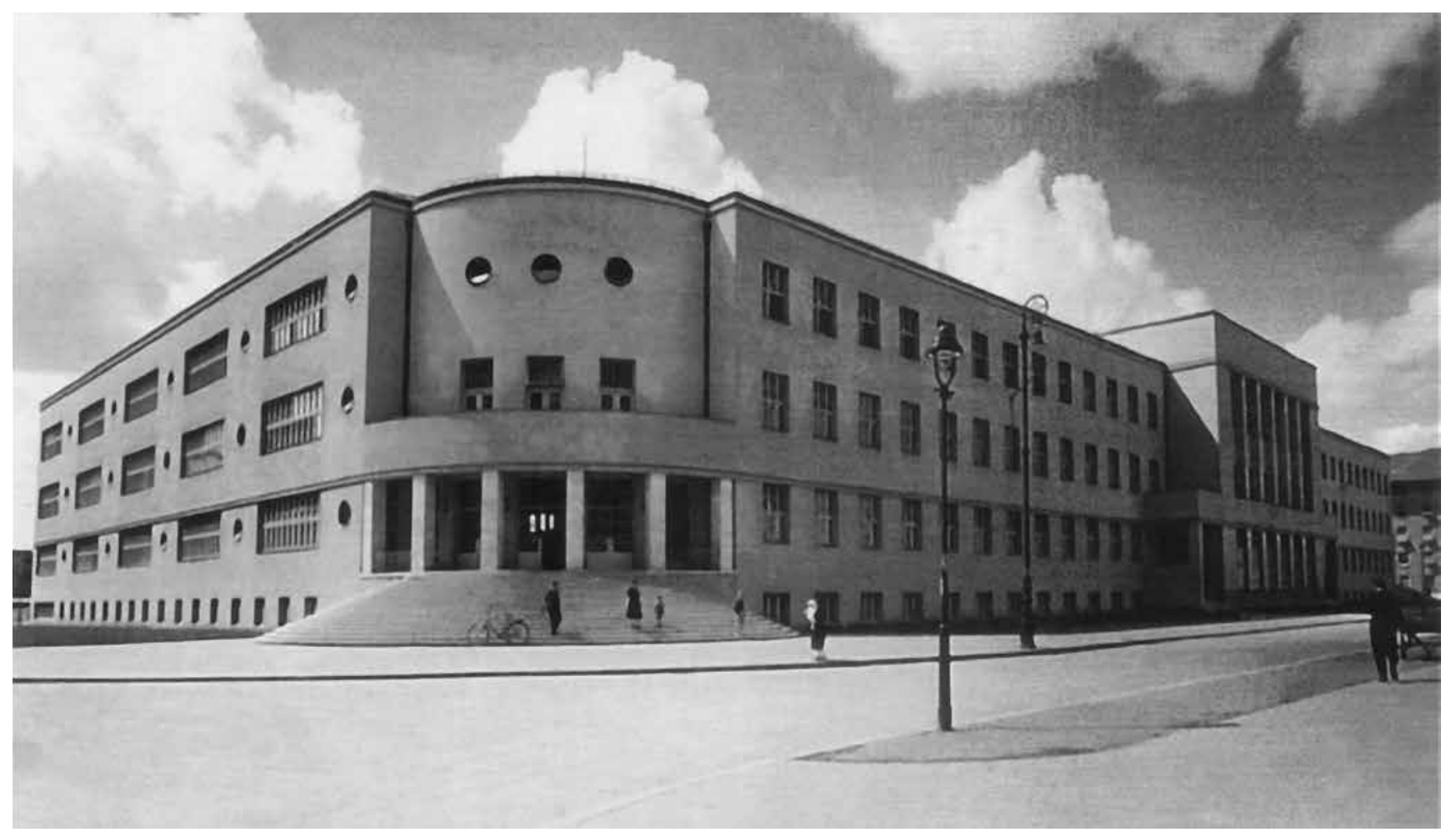

22. Monumentalni sklop državnih srednjih škola u Križanićevoj ulici, Egon Steinmann, 1930./1931.

The monumental assembly of the state high schools in Križanićeva Street, Egon Steinmann, 1930/1931

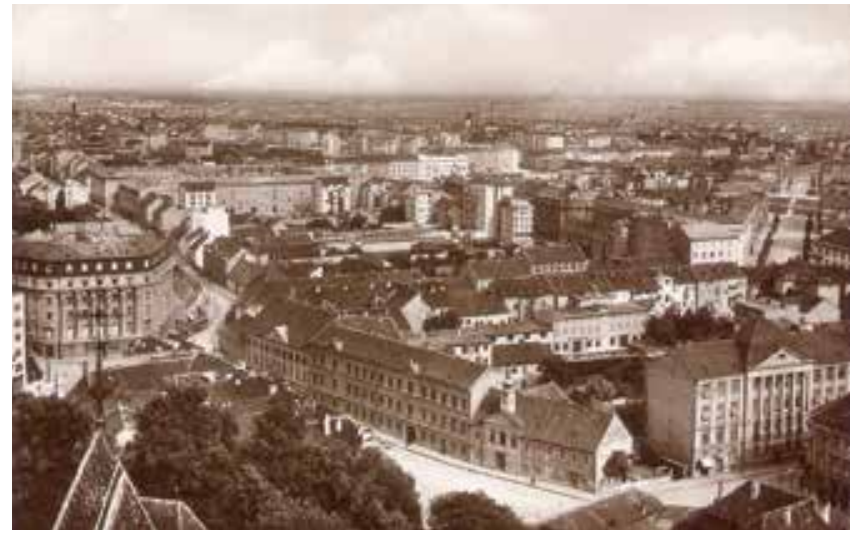

23. Fotografija s tornja katedrale prema gradskom istoku prikazuje prostor između Stare Vlaške i Vlaške te Račkoga ulice i Trga žrtava fašizma oko 1932. te bilježi prve primjere moderne funkcionalne arhitekture - visoke bijele kuće Wellisch Drage Iblera podignute na strani Vlaške i Martićeve ulice te, u sredini fotografije, stambenu zgradu Zagrebačke ledane Stjepana Planića u Bauerovoj ulici.

A photograph of the east part of the city taken from the cathedral tower around 1932 showing, among other, the first examples of modern functional architecture - two tall white office and apartment Wellisch buildings by Drago Ibler, built simultaneously in Vlaška and Martićeva streets, as well as, in the middle, the house of Zagreb Ice Factory in Bauerova Street, designed by Stjepan Planić

prometnoga čvorišta. Promjena regulatorne osnove za Krešimirov trg i predio između Krešimirovog trga i Zvonimirove ulice iz $1930 .{ }^{46}$ svjedoči o odustajanju od perivoja na njegovoj sjevernoj strani, čime sâm trg postaje perivoj. Osnovom je planirano simetrično rašljasto proširenje trga s južne

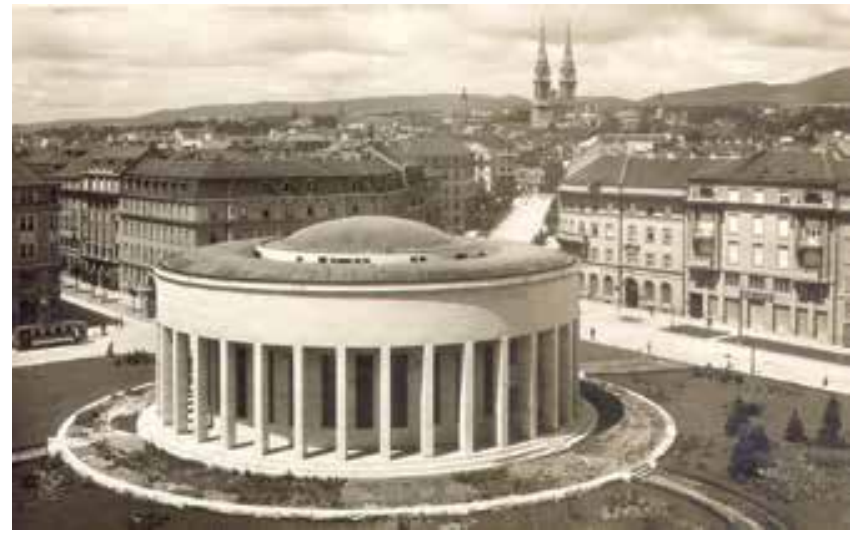

24. Ivan Meštrović, Zvonimir Kavurić, Harold Bilinić, Ivan Zemljak, Lavoslav Horvat, Nikola Molnar, Dom likovnih umjetnika, urbanistički i simbolički najvažnija građevina ovog djela grada, 1934. - 1938.

Ivan Meštrović, Zvonimir Kavurić, Harold Bilinić, Ivan Zemljak, Lavoslav Horvat, and Nikola Molnar, House of Artists, 1934-1938, urbanistically and symbolically most important building in this part of the city

strane, što neće biti izvedeno. Iako je sredinom 1920-ih započela sporadična izgradnja zapadne i istočne strane trga pojedinačnim kućama, tek mu je smisleno urbanističkoarhitektonsko-hortikulturno oblikovanje Vlade Antolića, Josipa Seissela i Cirila Jegliča u drugoj polovici 1930-ih dalo paradigmatska obilježja reprezentativnoga i intimnog trga ${ }^{47}$ Riječ je o nagradi i izvedbi na našemu prvom javnom natječaju za hortikulturno oblikovanje javnoga gradskog pro- 


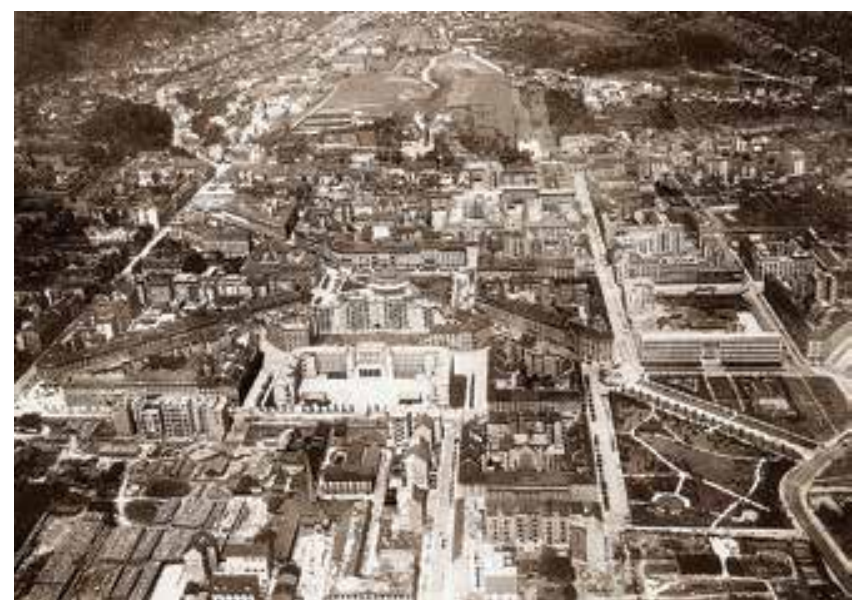

25. Pogled s juga na realizirani potez tri trga, oko 1935.

The completed three-square sequence, aerial view from the south, around 1935

stora u Zagrebu iz 1934. godine. ${ }^{48}$ Tijekom 1930-ih podižu se kapitalne monumentalne građevine pročišćenog izraza koje dominiraju sjevernom stranom trga: Državna trgovačka akademija Zvonimira Vrkljana (danas MORH, Krešimirov $\operatorname{trg} 1$ - Stančićeva, 1931. - 1938. ${ }^{49}$ i uglovnica Radničkog doma (ponovno s originalnom dvoranom) Vladimira Šterka i arhitekata Korka - Krekić - Kiverov (Krešimirov trg 2, 1935. - 1938.), koje će trgu odrediti karakter. ${ }^{50}$

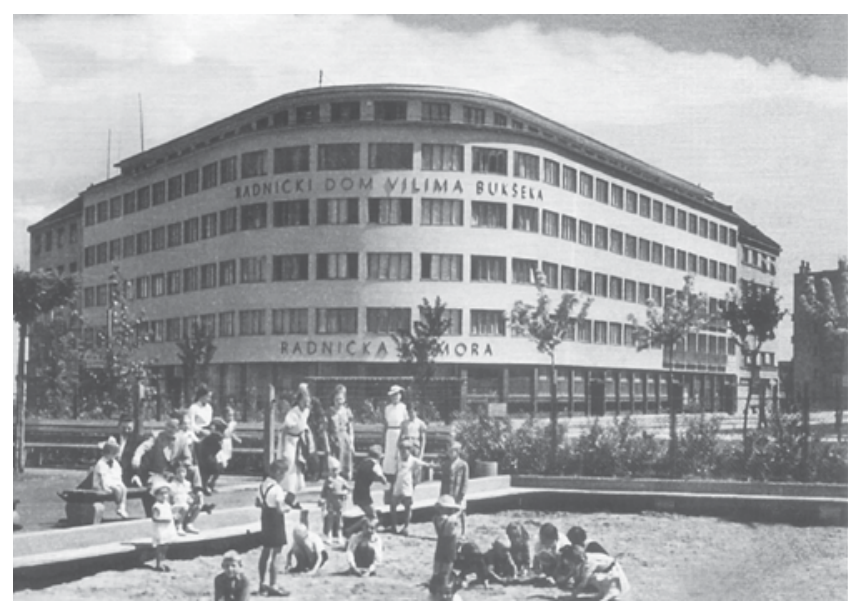

26. Radnički dom Vladimira Šterka, Jovana Korke, Đorđa Krekića Đorđa Kiverova (1935. - 1938.) i dječje igralište na Krešimirovom trgu, oko 1938

Workers' House, 1935-1938, designed by Vladimir Šterk, Jovan Korka, Đorde Krekić, and Đorde Kiverov, and the children' playground on Krešimir Square, around 1938

Krešimirov trg realiziran je kao najveći pojedinačni perivojni trg u međuratnom razdoblju u Zagrebu. Projektiranjem samog perivoja kao dvije različite cjeline; manja sjeveroistočna ortogonalno-geometrijskog je karaktera (sa suvremenim dječjim igralištem), a veća jugozapadna je pejzažno-organski oblikovana; Ciril Jeglič originalno je riješio sadržajne i

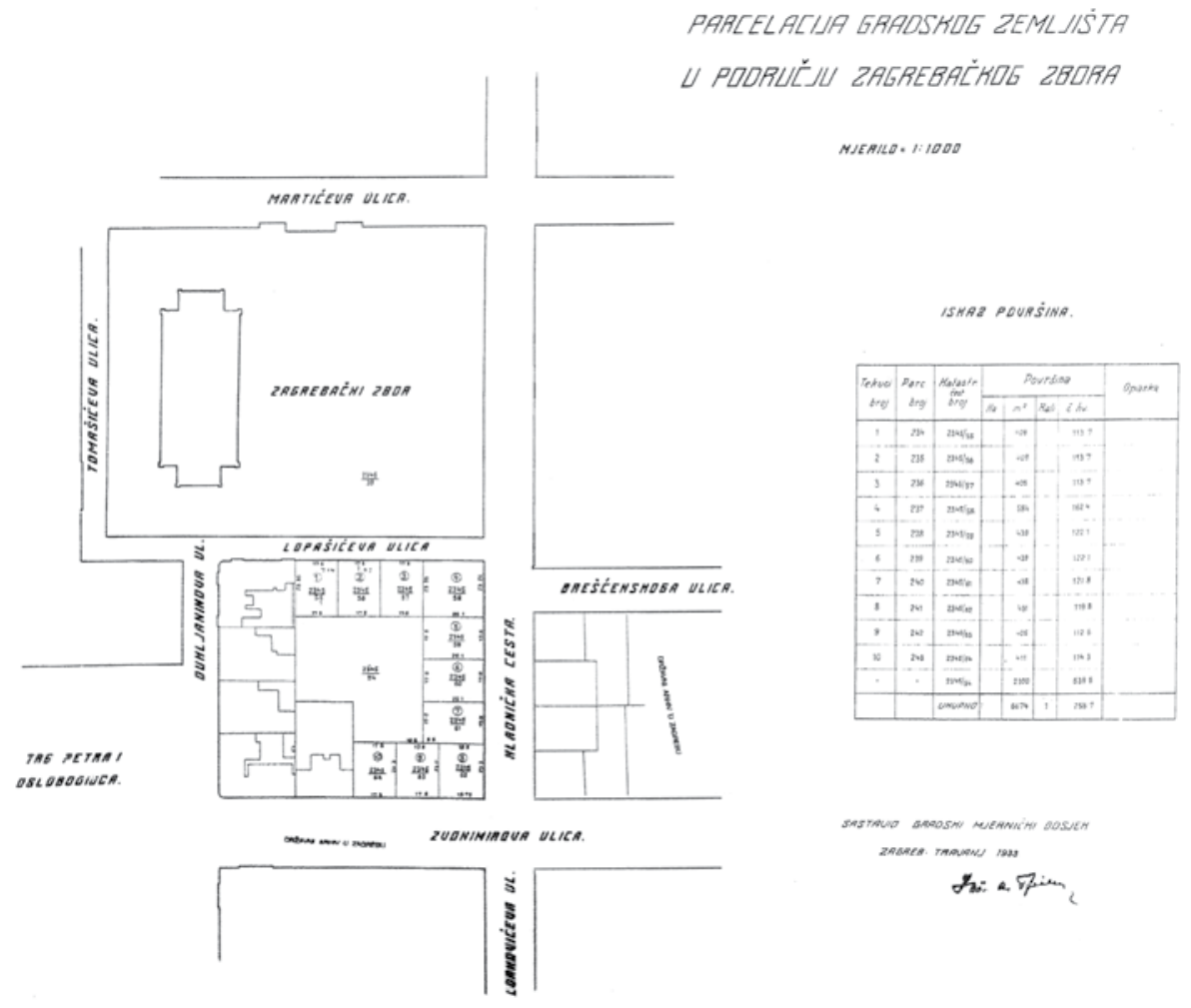

27. Parcelacija dijela zemljišta Zagrebačkog zbora, između Zvonimirove, Bauerove, Lopašićeve i Dukljaninove ulice 1933. (Državni arhiv u Zagrebu)

Allotment plan for a part of Zagreb Fairgrounds between Zvonimirova, Bauerova, and Lopašićeva streets in 1933 


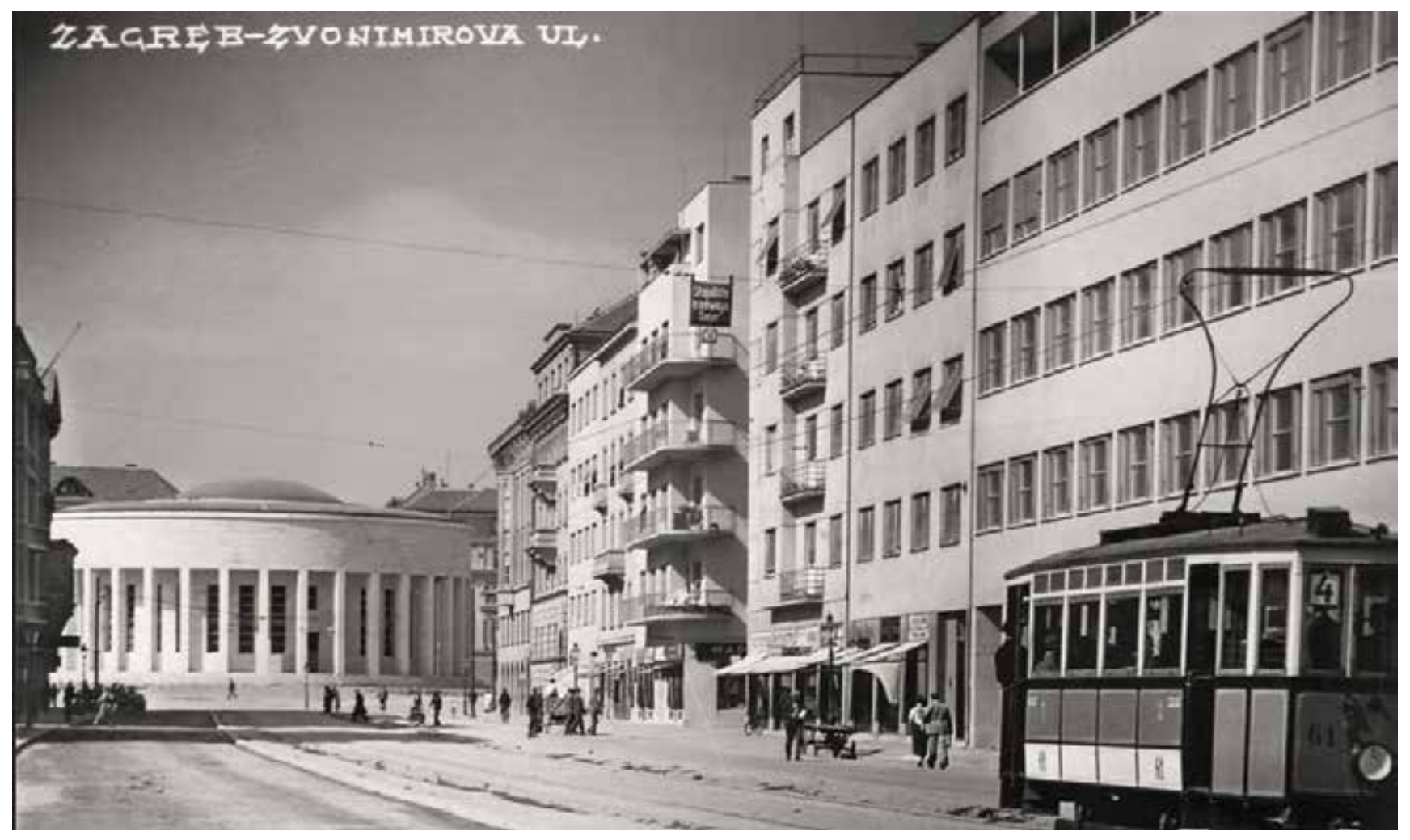

28. Zvonimirova ulica s novom uglovnicom uz Bauerovu Bogdana Petrovića i Javnu burzu rada Vladimira Šterka, oko 1937.

Zvonimirova Street with a new corner building next to Bauerova Street, designed by Bogdan Petrović, and the Public Labour Exchange by Vladimir Sterk, around 1937

društvene potrebe moderne zagrebačke četvrti. ${ }^{51} \mathrm{Od}$ male crkve planirane u jednoj fazi, koja se trebala smjestiti istočno od dječjeg igrališta uz Aveniju Marina Držića kao dio cjeline trga, poslije se odustalo.

Ekonomska kriza od 1929. do 1935. godine pojačala je ulaganje u nekretnine i građevinske radove, a Gradska općina financirala je izgradnju tramvajske pruge od Ulice Račkoga prema Zvonimirovoj. Špekuliranje kapitalom, utrka među investitorima, graditeljima i arhitektima, koji su ovdje vidjeli svoju poslovnu priliku, dali su pečat istočnijim dijelovima ovoga gradskog područja krajem 1930-ih i u početku 1940ih godina.

Nakon što je Zagrebački zbor 1936. preseljen u novoizgrađene paviljone na Savskoj cesti, uklonjena je Jašiona u Martićevoj čime je oslobođeno posljednje veliko atraktivno zemljište na istočnoj strani uz Bauerovu. $U$ godinu dana, 1936./37., niknut će pravokutni blok ujednačenih i ekonomičnih trgovačko-stambenih zgrada Martićeva Tomašićeva - Lopašićeva - Bulićeva. Najveću inventivnost u oblikovanju pokazao je Ibler projektirajući uglovnicu s novoprojektiranom Bulićevom ulicom, orijentirajući svoju kuću prema novome trgu, koji je nastao proširenjem donjeg toka Martićeve (Martićeva 14c). Ostale kuće u bloku prema tada uhodanom receptu najamnih stambenih kuća s tzv. »Zagrebačkim tlocrtom « grade već i građevinski poduzetnici, nerijetko bez arhitekata.

Velika građevinska aktivnost u razdoblju između dvaju svjetskih ratova omogućila je realizaciju dijagonalnog poteza trgova i okolnih blokova. I trgovi sami gotovo su u cijelosti tada sagrađeni; Trg hrvatskih velikana podizan je od 1921. do 1931. godine, Trg žrtava fašizma od 1922. do 1937. godine, Krešimirov trg od 1920-ih do 1950-ih. Gradska uprava nije vjerovala u toliki rast, pa se ubrzo pogrešnom pokazala odluka da se na glavnoj magistrali grada prema istoku Zvonimirovoj, već kod Heinzelove započne s predjelom obiteljskih kuća, umjesto da se nastavilo s trokatnicama i četverokatnicama. ${ }^{52}$

\section{Razdoblje nakon Drugoga svjetskog rata - kidanje tradicionalnih blokova i strategije interpolacije}

Poslijeratni prostorni planovi dio grada oko Trga žrtava fašizma namjenom svrstavaju u poslovno-stambenu zonu, koja se smatrala urbaniziranom (Nacrt grada Zagreba 1947.) i nije u fokusu urbanista, koji su se uspješno bavili svladavanjem zapreka širenju grada prema jugu; prvo u Trnje, a potom prelaskom rijeke Save i razvojem Novog Zagreba. ${ }^{53}$

Naglasak je na popunjavanju praznih parcela, pa se u ovom dijelu grada među prvim projektima našao onaj za koncertnu dvoranu u sklopu Doma JNA u Stančićevoj arhitekta Franje Zvonimira Tišine (1947. - 1949.), ${ }^{54}$ u sjevernom bloku uz Krešimirov trg. Na samom se trgu stambenim zgradama popunjavaju preostale parcele. Prazno mjesto na zapadnoj fronti do uglovnice s Višeslavovom, koju je 1928. podignuo Aladar Baranyai, popunit će stambenom četverokatnicom njegov 


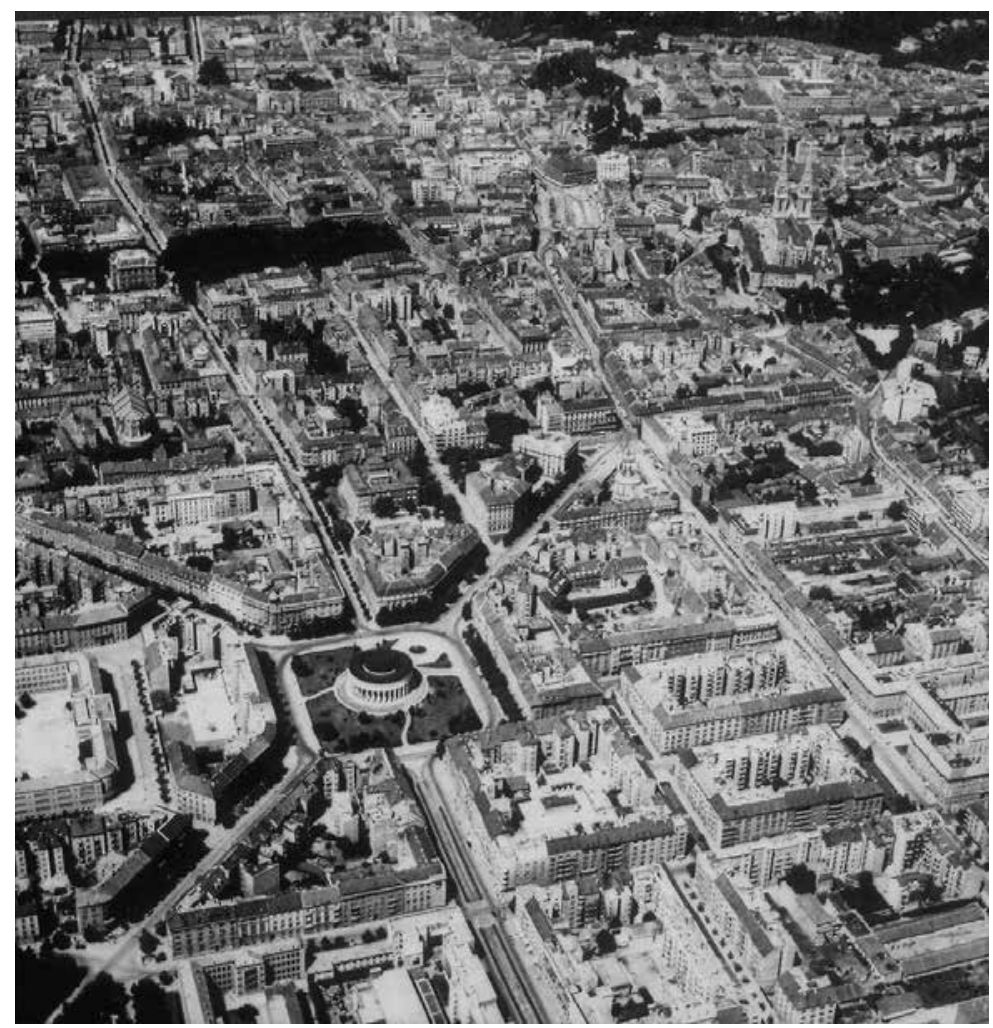

29. Istočni dio grada s Trgom žrtava fašizma na snimci iz zraka, oko 1945. (Hrvatski povijesni muzej)

Aerial view of the east part of the city with the Square of the Victims of Fascism, around 1945

sin Pavao Baranyai, projektant biroa Žerjavić (Krešimirov trg 19, 1957.). ${ }^{55}$ Uglovnicom arhitekta Marjana Haberlea Krešimirov trg - Kraljice Jelene 1 (1954. - 1957.) zaokružen je u cijelosti izgled trga, toga jugoistočnog ulaza u povijesnu jezgru, projektiranom zelenom magistralom triju trgova. ${ }^{56}$ Posebno uspješnima ocijenjene su interpolirane stambene zgrade koje Vladimir Turina podiže u Križanićevoj 5-11 (s elementima balkona kakve nalazimo na zgradi Bauhausa u Dessauu 1930-ih), ${ }^{57}$ Antun Ulrich na uglu Vojnovićeve i Martićeve 49 (obje 1953.), Zlatko Neumann u Martićevoj 46 (1959.). ${ }^{58}$ Rubna Branimirova ulica gradi se od 1940-ih do 1970-ih stambenim zgradama za radnike i namještenike obližnjih tvornica i poduzeća, ali neizgrađenih zemljišta uz nju ima i danas.

Od sredine 1950-ih interpolacije u rubne zone (istočnu i južnu) ne slijede više načelo subordinacije niti zadanu uličnu liniju. ${ }^{59}$ Urbanisti i arhitekti usvojili su strategiju koja naglašeno favorizira kidanje tradicionalnih blokova. Novi ambijent ostvario je interpoliranom kompozicijom zgrade za oficire JNA Slavko Jelinek u Trpimirovoj ulici (kbr. 9-15, 1953. - 1956.), ${ }^{60}$ a potom je za istog investitora u paralelnoj Domagojevoj ulici podignuta skupina deseterokatnih stambenih nebodera kvadratnog tlocrta (1966.).

Društveno zadana "racionalizacija stambene izgradnje» favorizirala je stambena naselja i blokove zacrtane u širem potezu. ${ }^{61}$ Po načelu urbanizma slobodnog plana u produljenoj Martićevoj nastao je stambeni mikrorajon, čije je zelenilo

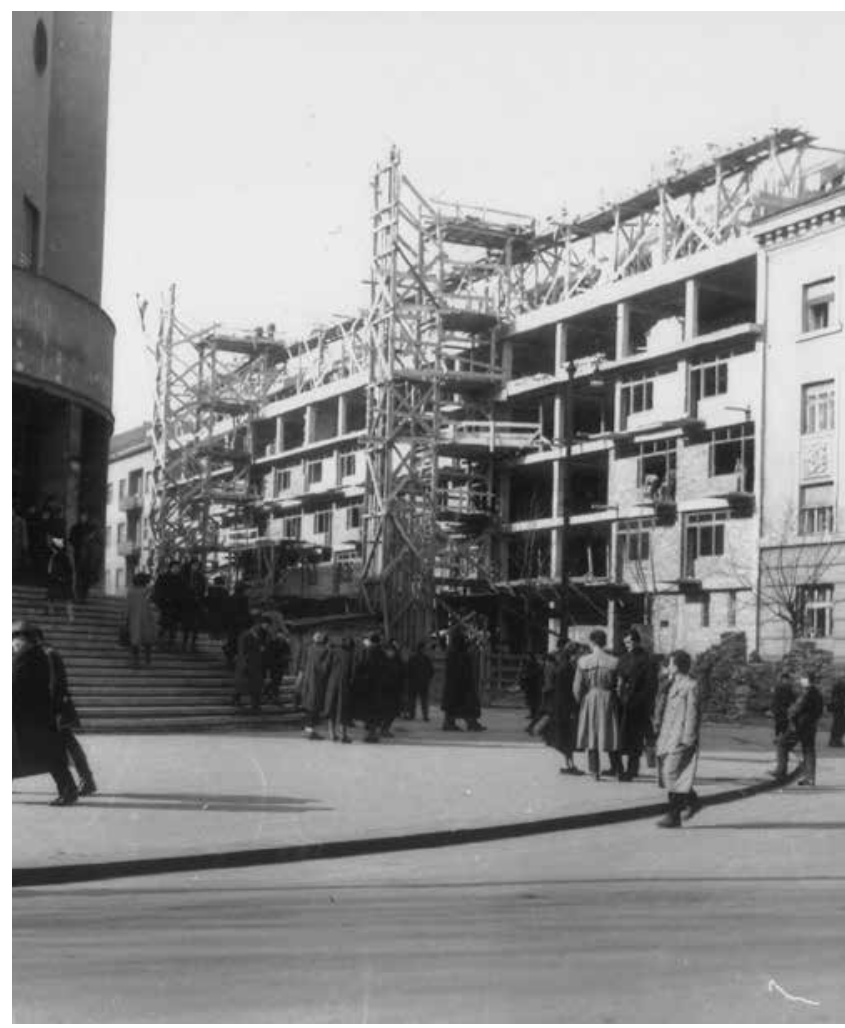

30. Interpolacija stambenih zgrada Vladimira Turine u Križanićevoj ulici 5-11, 1954. (Muzej Grada Zagreba)

Vladimir Turina, interpolation of apartment buildings in Križanićeva Street 5-11, photo taken in 1954

dalo ugodan nov okvir ulici (Ivan Zemljak, Zvonimir Frölich, Milan Žerjavić, Vladimir Turina, 1948. - 1957.). ${ }^{62}$

Koncepcija suvremene interpolacije važnost pripisuje mikrourbanističkom planiranju i kreativnosti, revitalizaciji i ako treba - kontrastu. Interpoliranje strukture koja nadvisuje okolnu gradnju predstavljena je na plemenit, nov i miran način promišljenom urbanističkom dispozicijom arhitektonskim rješenjem sklopa stambenih zgrada Ivana Vitića u Laginjinoj 9 (1958. - 1962.). Ono što je dotad bio zatvoreni gradski blok, ponuđeno je kao proširenje ulice i mali trg. ${ }^{63}$ I prozračan Dom zdravlja Medveščak s pristupnim hodnicima-balkonima Zoje Dumengjić u nastavku ulice (dovršen 1960.) pribrojio se reprezentativnim primjerima poslijeratnoga arhitektonskog modernizma.

Obnovljeni interes za ovaj gradski predio izazvala je intervencija u najstariji blok zone Vlaška - Draškovićeva - Martićeva - Iblerov trg, koji je dosad ostao netaknut. Okomit prodor koji je učinio tzv. Drveni neboder Drage Iblera (Iblerov trg 7, 1955. - 1958.) izazvao je mnoge rasprave arhitekata i konzervatora, te više naknadnih idejnih urbanističkih i arhitektonskih natječaja. ${ }^{64}$ Izgradnjom nebodera ostala je neriješena situacija neizgrađenog dijela bloka sjeverno od njega, kao i niza zatečenih dotrajalih zgrada uokolo. Većina prigovora odnosila se na kontekst jer neboder ne samo da »nelogično strši uklopljen u koridorsku izgradnju Martićeve,$^{65}$ nego i svi ostali dodiri, smatralo se, govore o nesraštenosti, neprilagodljivosti i nepriznavanju okoline. Nositelj međuratne 


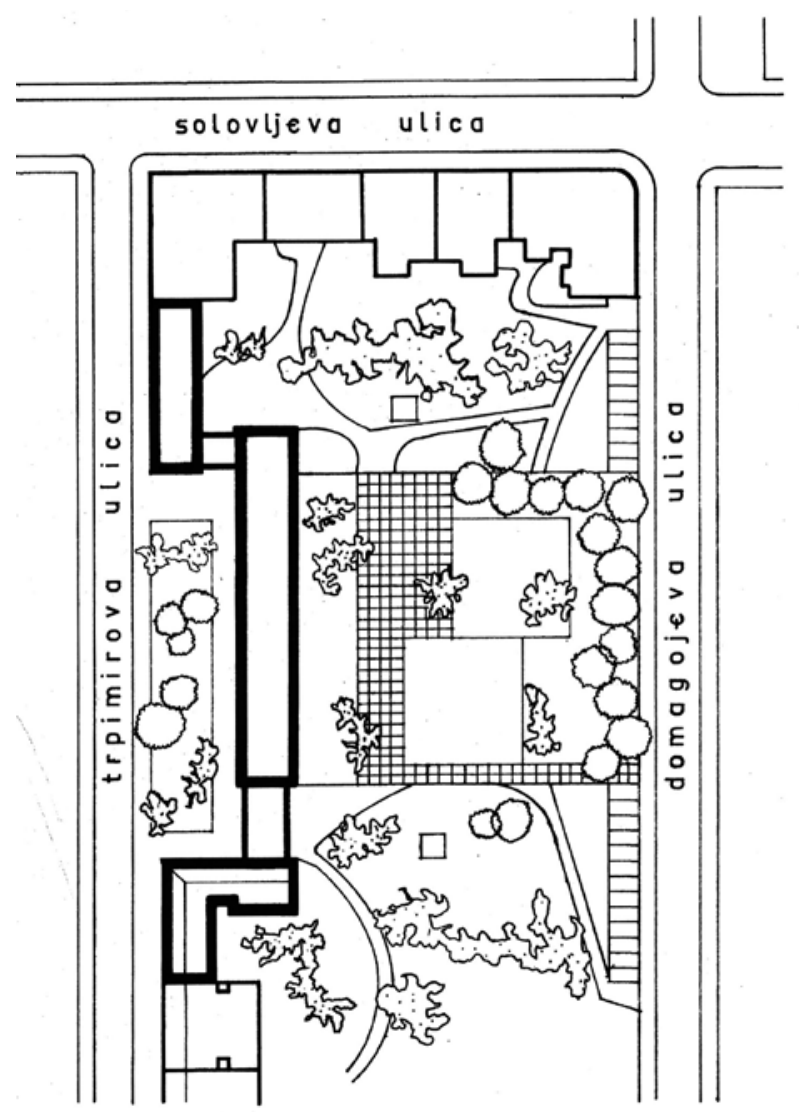

31. Situacija bloka Bornina (Solovljeva) - Trpimirova - Branimirova - Domagojeva s interpoliranim stambenim zgradama Slavka Jelineka u Trpimirovoj ulici 9-15, 1956. (arhiv S. Jelineka)

Situation plan of the Bornina (Solovljeva) - Trpimirova - Branimirova - Domagojeva block with interpolated apartment buildings designed by Slavko Jelinek, 1956

arhitektonske avangarde velikoga teorijskog i praktičnog značenja u našoj arhitekturi Drago Ibler tom se visokogradnjom, u neposrednoj blizini Kovačićeve Burze, zauvijek interpolirao u vizuru Trga hrvatskih velikana i Martićeve, kao sastavni dio evolucije grada. Martićeva ulica, građena "u valovima", pokazala se kao dobar i otporan primjer ulice umjerenog prometa, naklonjena sporijem kretanju pješaka i njihovom zadržavanju, što zanimljivostima koja prizemna zona kuća nudi, što proširenjima i zelenilom, a među kojima i tri Iblerove kuće imaju važnu funkciju (Martićeva 7, 13, 14c).

U bloku kroz Iblerov trg projektirani su naknadno pješački koridori (arh. A. Glunčić, 1963.), ${ }^{66}$ a Regionalni zavod za zaštitu spomenika kulture 1970-ih donosi konzervatorske uvjete uređenja bloka, u kojima inzistira na očuvanju starijih tradicionalnih kuća uz Vlašku. ${ }^{67}$ Za potrebe Generalnoga urbanističkog plana grada Zagreba 1971. nadležna služba zaštite spomenika predlaže i proširenje granice zaštite područja Donjega grada - na istoku do Krešimirova trga. Pojas Draškovićeve i stare Vlaške do Kvaternikova trga obuhvaćen je već Rješenjem o zaštiti urbanističke cjeline Stari grad Zagreb iz 1965. godine. ${ }^{68}$

Urbanistički zavod grada Zagreba radi 1975. godine program natječaja za Iblerov trg, ${ }^{69}$ na kojem je već prisutna interpo-

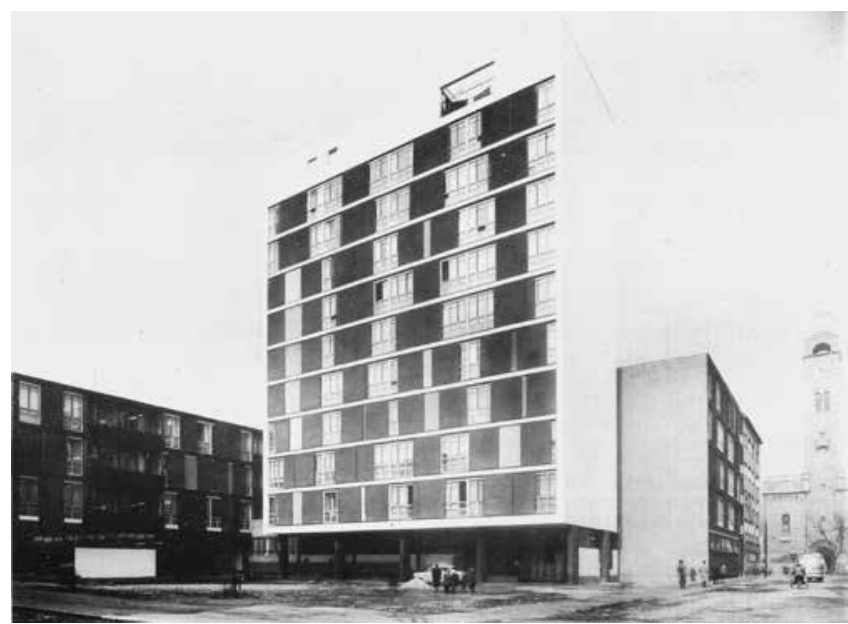

32. Sklop stambenih zgrada s malim trgom Ive Vitića u Laginjinoj ulici, 1962.

Assembly of apartment buildings with a small square by Ivan Vitić in Laginjina Street, 1962

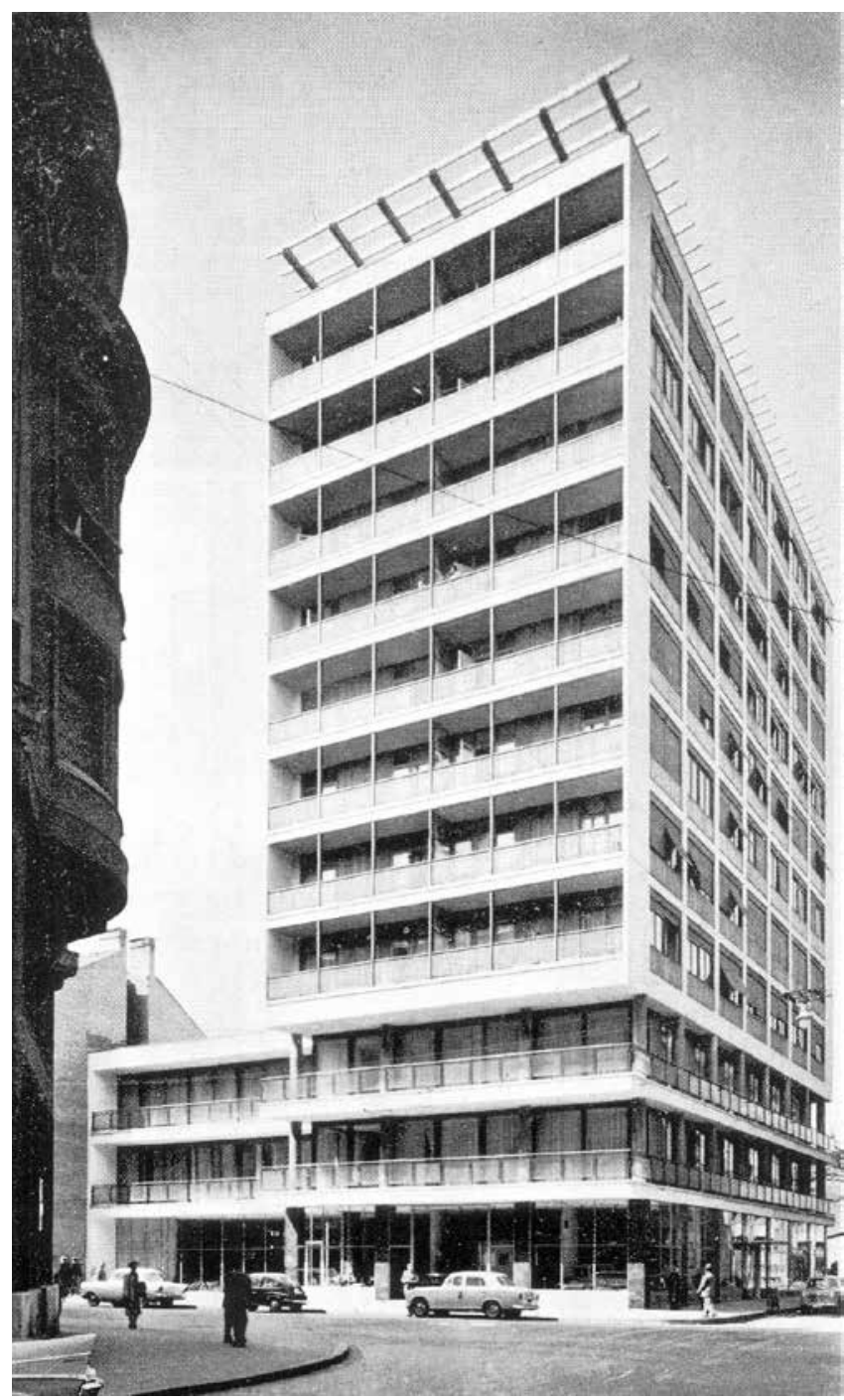

33. Dovršeni Drveni neboder Drage Iblera u Martićevoj ulici, 1958. The so-called Wooden Skyscraper, designed by Drago Ibler, Martićeva 7, 1958 


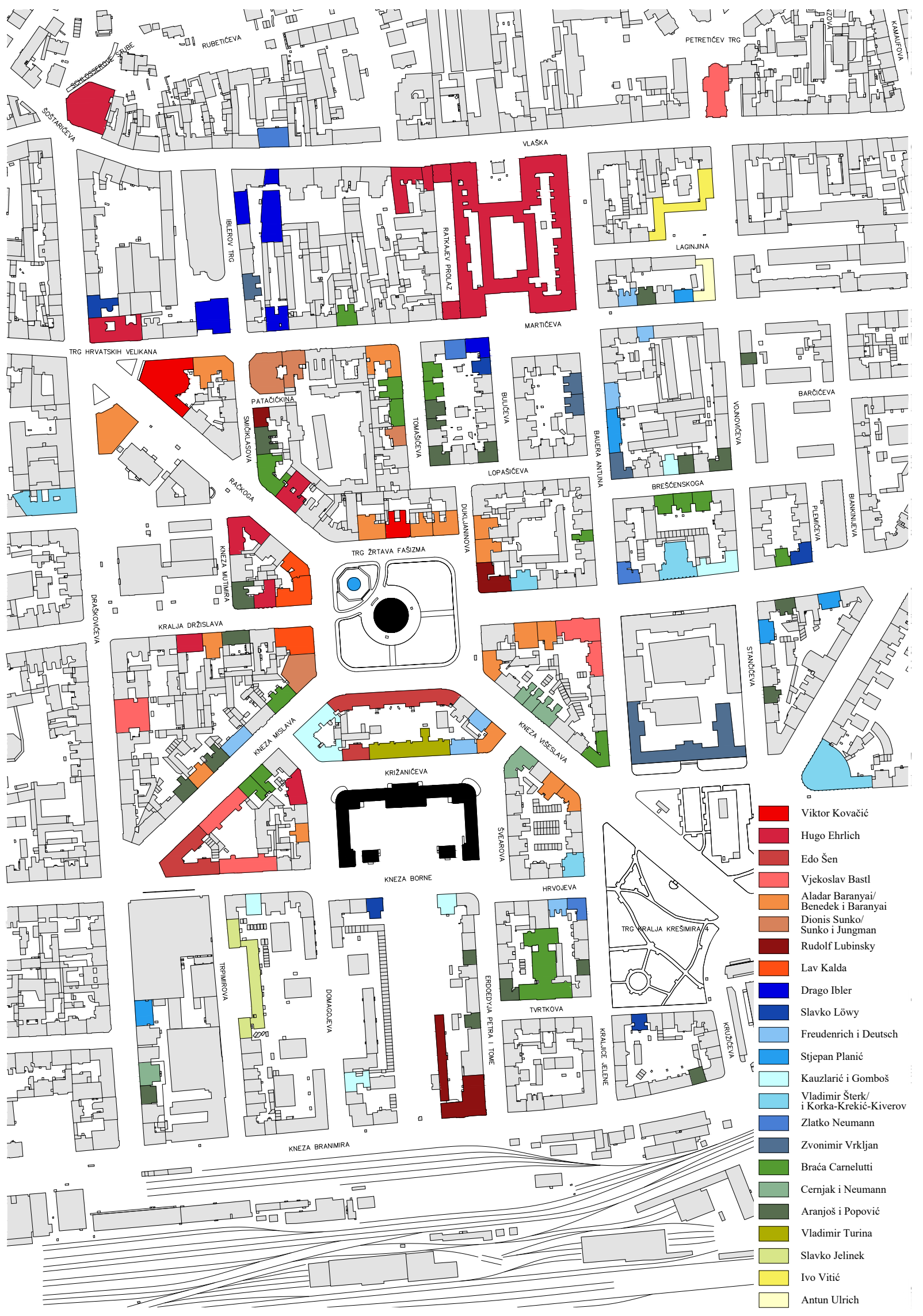

34. Karta dijela autora zastupljenih u izgradnji područja Draškovićeva - Vlaška - Bauerova - Branimirova (prema građevinskoj dokumentaciji Državnog arhiva u Zagrebu, crtež arh. Dora Šantek, 2020.)

Some of the architects who built the area between Draškovićeva, Vlaška, Bauerova, and Branimirova Streets 

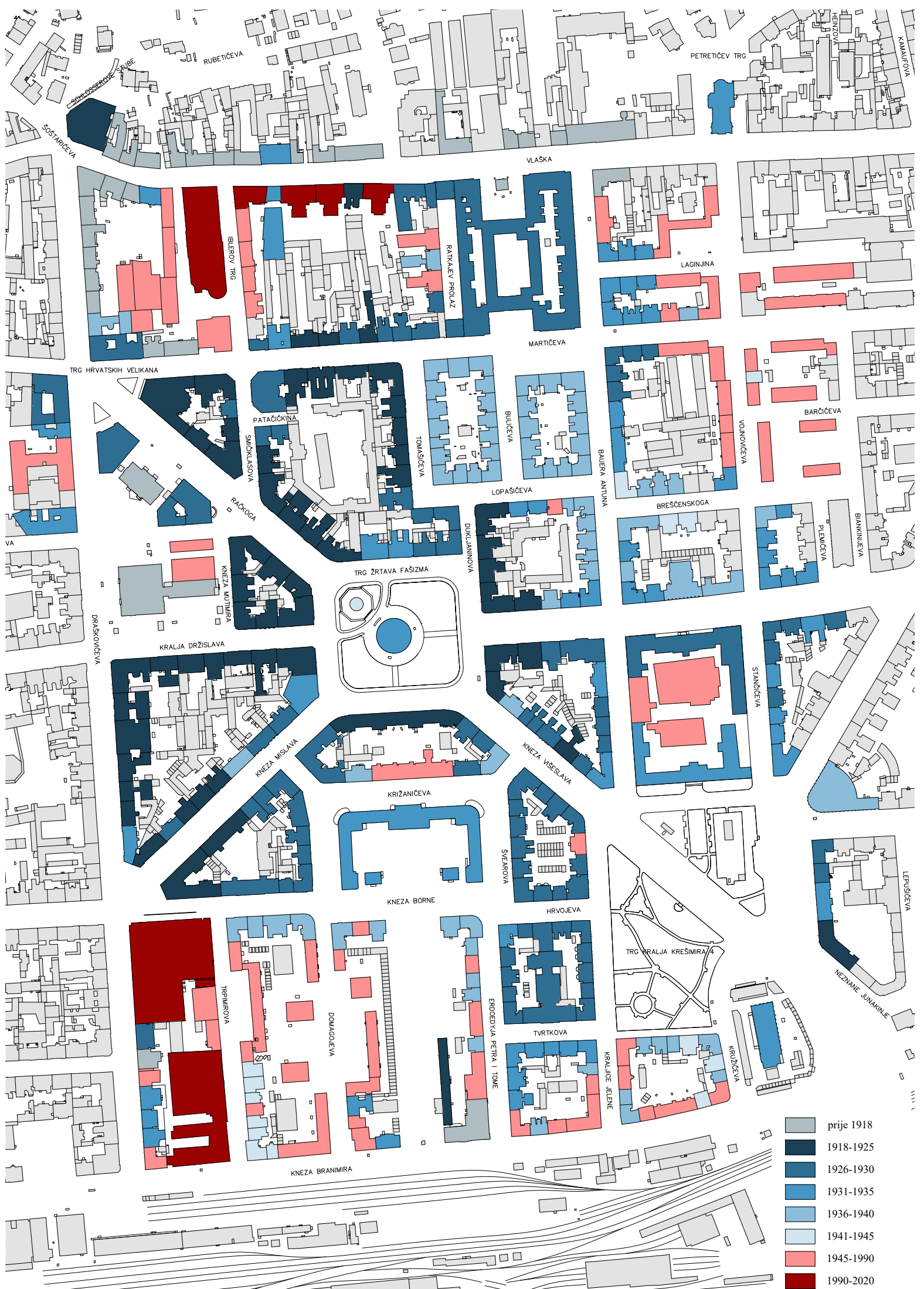

35. Vremenska karta izgradnje područja Draškovićeva - Vlaška - Bauerova - Branimirova (prema građevinskoj dokumentaciji Državnog arhiva u Zagrebu, crtež arh. Dora Šantek, 2020.)

Timeline of the construction of the area between Draškovićeva, Vlaška, Bauerova, and Branimirova Streets 
lacija novoga umirovljeničkog doma (ubožnica se u istom bloku nalazila od 1865.). Nagrađeni projekt rekonstrukcije Iblerova trga Branka Silađina i Berislava Šerbetića ${ }^{70}$ ruši stare kuće u istočnom dijelu, trg rubi drvoredom i otvara ga prema Vlaškoj i Šalati. ${ }^{71}$ Regionalni zavod manje destruktivnim protuprijedlogom nudi pješačku vezu sa Šalatom kroz već postojeće kuće i dvorišta. ${ }^{72}$ Obje su inicijative ostale nerealizirane. Više od desetljeća kasnije, kada se brojne bitno veće trgovačko-stambene zgrade podižu na južnoj strani Vlaške uza Smičiklasovu, prostor Iblerova trga postaje predmetom novoga urbanističko-arhitektonskog natječaja 1991. godine. Tražilo se idejno rješenje za poslovno-stambeni sklop, tzv. Kompleks Iblerov $\operatorname{trg}{ }^{73}$ čiji je rezultat zdanje Importanne galerije, kojim je sam trg sveden na koridor unutar okolne gradnje.

Godine 1967. izrađeno je u Urbanističkom zavodu grada Zagreba rješenje za blok Draškovićeva - Solovljeva (Bornina). ${ }^{74}$ Uslijedio je uži natječaj za urbanističko-arhitektonsko idejno rješenje poslovne zgrade na južnom spoju tih dviju ulica (potencijalni Vjesnikov neboder). Podsjetiti se treba Lenucijeve dileme i prepiranja s Hrvatskim društvom inžinira i arhitekta iz 1905. godine za rješenje istočne strane toga istog raskrižja. Prvonagrađeni rad Petera Vovka, koji je predlagao sklop zgrada s dominantnom visokogradnjom ispred kojih bi se formirao mali trg, nije bio izveden. ${ }^{75}$ Kao rezultat ponovnog natječaja 1986. godine za istu lokaciju podignut je Hotel Sheraton arhitekta Marijana Turkulina 1995. godine. Na krajnjem jugu istog bloka nastaje višefunkcionalna poslovna zgrada Branimir centra s kinodvoranama i hotelom 2003. godine (Draškovićeva 57 - Branimirova 29).

\section{Bilješke}

1

Nacrt Zagreba. Izdao pomoćju gradskog mjernika Dragutin Albrecht 1864., Muzej grada Zagreba, Zbirka planova.

\section{2}

Regulatorna osnova grada Zagreba 1865., Nacionalna i sveučilišna knjižnica, Zbirka zemljovida. Nacrti grada Zagreba i regulacije u ovom članku načinjeni su prema: PAŠKKO LOVRIĆ (ur.), Zagreb na geodetsko-katastarskim zemljovidima i u zemljišnim knjigama, katalog izložbe, Umjetnički paviljon, Zagreb, 1994.; DARJA RADOVIĆ MAHEČIĆ - SANJA ŠTOK, Regulatorne osnove grada Zagreba 1850-1950, elaborat, Gradski zavod za planiranje razvoja i zaštitu čovjekova okoliša iz Zagreba, 1996.

3

Nacrt grada Zagreba 1878. Sastavio Gradski gradevni ured, Muzej grada Zagreba, Zbirka planova.

4

Nacrt grada Zagreba 1889. Regulatorna osnova, Sastavio Gradski građevni ured, Muzej grada Zagreba, Zbirka planova (pojednostavljena tiskana verzija rukopisne regulatorne osnove iz 1887.).
Realizaciji višedesetljetne želje da dvije dijagonalne ulice koje vode prema Trgu žrtava fašizma - Račkoga i Mislavova - od Draškovićeve krenu s malih trokutastih trgova, pristupilo se 1994. redizajniranjem tih javnih prostora. S Trga Burze, dotad uglavnom parterno uređivanog, uklonjene su skulpture i zelenilo, ne bi li ih zamijenile simetrične trokutaste fontane (kojima se, među ostalim, izjednačavaju fronte Kovačićeve Burze i Baranyajeve zrcalne kuće, ali i trajno vlagom uništava sama zgrada Burze), što u javnosti nije prošlo bez otpora. ${ }^{76}$ Južniji pandan, spoj Bornine i Mislavove, koji je godinama bio sumoran i neatraktivan, uređenjem je dobio originalan primjer urbane opreme: od poda odignuti trokutasti podest, koji je istovremeno i klupa i postolje javne skulpture, ali ne i status trga.

Gradovi su mjesta stalne evolucije i svaki društveni ili prirodni izazov na njima ostavi trag i bitno utječe na njihovu budućnost. Područje Zagreba istočno od Draškovićeve ulice razvijalo se u 20. stoljeću s ambicijama velegrada. Nezaobilazna vrijednost te zone ostaje ideja ozelenjene dijagonalne trase koja spaja tri trga, kao visoko estetiziranoga, ali i funkcionalnog prostora, u kojem se omjer javnoga i privatnoga stalno mijenja. Istočni dio središta grada primjer je afirmacije i mjestimične revitalizacije onoga što su dosadašnje generacije stvorile, kao i resetiranje drugih nekih dijelova za suvremene potrebe. Zahvati unutar zaštićenih zona nameću potrebu za odgovarajućim planom, i sada smo u iščekivanju onoga za obnovu i revitalizaciju Zagreba nakon potresa 2020. godine.
Vidjeti i: SNJEŠKA KNEŽEVIĆ, Urbanističke osnove Zagreba u razdoblju modernizacije, Peristil, 62 (2019.), 29-32.

5 EUGEN FRANKOVIĆ, Lenucijeva era, Arhitektura, 204-207 (1988.), 81-111.

6

Nacrt grada Zagreba 1898. Sastavio Gradski gradevni ured, Muzej grada Zagreba, Zbirka planova. Potok Medveščak bio je dijelom nadsvođen, a dijelom reguliran novim koritom 1896. godine.

7

Situacija novog i pokrivenog toka potoka Medveščaka, Državni arhiv u Zagrebu, Zbirka regulacijskih planova. Stari i novi tok potoka Medveščaka razdvajaju se sjeverno od Gupčeve zvijezde. Stari tok potoka išao je zapadno od Gupčeve zvijezde Kožarskom i Tkalčićevom ulicom, uza stražnju stranu kuća sjeverne strane Jelačićeva trga, kratko po Jurišićevoj, dijagonalno preko bloka Palmotićeva - Đorđićeva i dalje u smjeru Đorđićeve do Klaoničke (Bauerove) prema Kanalu, južno od željezničke pruge. Novi tok natkrivenog potoka Medveščaka kreće od istočne strane Gupče- 
ve zvijezde, pod ulicama Medveščak - Ribnjak - Draškovićeva - Račkoga, pod Trgom žrtava fašizma, pa Višeslavovom prema Kanalu južno od pruge.

8

Nacrt grada Zagreba, Izdao i štampao Svjetlotiskarski zavod R. Mosinger d. d. Zagreb. Prilog k Zagrebačkom adresaru god. 1911., Državni arhiv u Zagrebu, Zbirka regulacijskih planova.

9

SNJEŠKA KNEŽEVIĆ, Regulatorna osnova Milana Lenucija za dio Zagreba od željezničke pruge do rijeke Save, Radovi Instituta za povijest umjetnosti, 16 (1992.), 169-197.

10

Regulatorna osnova sl. i kr. grada Zagreba. Dio istočno od Draškovićeve ulice između Vlaške ulice i kr. ug. Državne željeznice, izr. Milan Lenuci, 1905., Državni arhiv u Zagrebu, Zbirka regulacijskih planova.

11

Regulatorna osnova grada Zagreba. Dio od Draškovićeve ulice prema Maksimiru, Gradski građevni ured, Milan Lenuci, kolovoz 1909., Državni arhiv u Zagrebu, Zbirka regulacijskih planova.

12

JANKO HOLJAC - MILAN KREKOVIĆ, Osnova za regulaciju iztočnoga diela kr. slob. i glavnoga grada Zagreba, Viesti Hrvatskoga društva inžinira i arhitekta, 3 (1905.), 34-37.

13

EUGEN FRANKOVIĆ (bilj. 5), 81-82.

14

Kao 10.

15

Regulatorna osnova za gradilište i cestu za Zemaljsku bolnicu na Šalati, izr. Milan Lenuci, 1905., Državni arhiv u Zagrebu, Zbirka regulacijskih planova.

16

MILAN PRELOG (ur.) - ŽELJKA ČORAK - LELJA DOBROVIĆ - EUGEN FRANKOVIĆ, Povijesni identitet sjevernog područja grada Zagreba - podbrežja Medvednice, elaborat, Urbanistički zavod Grada Zagreba, Zagreb, 1980.

17

Sve varijante crtane su na podlozi: Regulatorne osnove sl. $i \mathrm{kr}$. grada Zagreba. Dio istočno od Draškovićeve ulice između Vlaške ulice $i$ kr. ug. Državne željeznice, travanj 1905., siječanj 1909., Državni arhiv u Zagrebu, Zbirka regulacijskih planova.

18

MARINA PRETKOVIĆ, Tvornica "Nada Dimić" - povijesni pregled, problemi zaštite i mogućnost revitalizacije, Godišnjak zaštite spomenika kulture Hrvatske, 37-38 (2013. - 2014.), 119-132.

19

Nacrt Zagreba sastavio za načelnikovanja arhitekta Vjekoslava Heinzela god. 1923. Gradski gradjevni odsjek ing. Karlo Vajda, Muzej grada Zagreba, Zbirka planova.

20

STJEPAN HRIBAR, Razvitak Zagreba 1919.-1929., u: Rajko Kuščević (ur.), Jugoslavija na tehničkom polju 1919.-1929., Zagreb, 1930., 244.

21

Perspektivna panorama Zagreba (pogled s jugoistoka) iz 1926., tiskana u Pragu, u: PAŠKO LOVRIĆ (bilj. 2), 102-103.
22

Regulatorna osnova grada Zagreba. Promjena osnove predijela između Vlaške ulice i Petrove ulice, Milan Lenuci, 1909., Državni arhiv u Zagrebu, Zbirka regulacijskih planova; ZORANA SOKOL GOJNIK, Sakralna arhitektura Zagreba u 20. stoljeću, Zagreb, 2017., 27.

23

IVO VINSKI, Investicije na području Hrvatske u razdoblju izmedu dva svjetska rata, Beograd, Ekonomski institut FNRJ, 1953.; IGOR KARAMAN, Industrijalizacija građanske Hrvatske (1800-1941), Zagreb, Naprijed, 1991., 268-283.

24

ALEKSANDER LASLO, Arhitekt Viktor Kovačić 1874.-1924., Čovjek i prostor, 10 (1984.), 6-7.

25

STJEPAN SZAVITS-NOSSAN, Novogradnja palače zagrebačke burze, Bankarstvo, 2 (1924.), 73-76.

26 STJEPAN SZAVITS-NOSSAN, Prof. Arh. Viktor Kovačić, Tehnički list, 6 (1925.), 82.

27

Financijske ustanove, banke i osiguravajuća društva, koji su investirali u izgradnju ovog dijela grada: Jadransko osiguravajuće d. d., Prva hrvatska štedionica, Jadranska banka, Hrvatska gospodarska banka, Hrvatska eskomptna banka, Penzioni fond namještenika općeg jugoslavenskog bankarskog društva d. d., hrvatska podružnica Wiener Bank-Vereina, Centralna banka za trgov. obrt i ind. d. d., Hrvatska poljodjelska banka, Glavna bratimska blagajna za osiguranje rudarskih radnika, Dunav osiguravajuće društvo d. d., Jugoslavenska banka d. d., Međunarodna banka d. d., Hrvatska sveopća prometna banka d. d., Slavenska banka, Mirovinska zaklada namještenika gradske štedionice općine grada Zagreba, Osiguravajuća zadruga Triglav, Općinski mirovinski fond itd. Prema građevinskoj dokumentaciji za pojedine kuće u Državnom arhivu u Zagrebu.

28

Dionička društva koja su investirala u izgradnju ovog dijela grada: Domovinska proizvodnja drva d. d., Prvo jugoslavensko dioničko društvo za šumsko gospodarstvo i industriju, Dioničko društvo za eksploataciju drveta, Jugoslavensko građevno poduzetništvo, Direkcija šuma, Zagrebačko građevinsko d. d., Danica dioničko društvo za kemijske proizvode, Jugoslavensko građ. d. d., Varaždinska industrija svile d. d., Zagrebačka ledana d. d., Pionir d. d., Tekstil d. d., Pruga - hrvatsko dioničko društvo za gospodarske i industrijalne željeznice, Omega dioničko društvo za gradnju kuća. - Prema građevinskoj dokumentaciji za pojedine kuće u Državnom arhivu u Zagrebu.

29

OLGA MARUŠEVSKI, Poslovna zgrada - tema 19. stoljeća, Čovjek i prostor, 360 (1983.), 30.

30

STJEPAN HRIBAR (bilj. 20), 240.

31

ALEKSANDER LASLO, Aladar Baranyai i građanski ideal, Arhitektura, 186-188 (1983. - 1984.), 64-73.

32

DRAGAN DAMJANOVIĆ, Zagreb. Arhitektonski atlas, Zagreb, 2014.; ZLATKO KARAČ - ALEN ŽUNIĆ, Arhitektonski vodič 
Zagreba, Zagreb, 2013.; ALENKA KOŠIŠA ČIČIN-ŠAIN, Donjogradske uglovnice kao element prostorne artikulacije grada, magistarski rad, Arhitektonski fakultet, Zagreb, 1986.

33

Građevinska dokumentacija za pojedine kuće prema adresi u: GPZ, GO, Državni arhiv u Zagrebu.

34

Naši arhitekti Edo Šen i Hugo Ehrlich, Hrvatska revija, 8 (1930.), 4.

35

ZVONIMIR VRKLJAN, Prof. Inž. Arh. Edo Šen (1877-1977), Čovjek i prostor, 4 (1977.), 28.

36

ŽARKO DOMLJAN, Arhitekt Ehrlich, Zagreb, 1979.

37

DARJA RADOVIĆ MAHEČIĆ, Socijalno stanovanje međuratnog Zagreba, Zagreb, 2002., 92-93.

38

Generalni regulacioni plan za grad Zagreb 1936., Državni arhiv u Zagrebu, Zbirka regulacijskih planova.

39

Svijet, 20, 13. 5. 1937., naslovnica.

40

Nacrt slob. i kr. grada Zagreba, Gradski građevni odsjek, 1932. i Nacrt grada Zagreba, Gradski mjernički odsjek, 1934-35., Državna geodetska uprava.

41

Osnova za uređenje Trg kralja Petra, Grad. gradj. XVII otsjek za reg. grada, Zagreb, srpanj 1932., Državni arhiv u Zagrebu, Zbirka regulacijskih planova.

42

ŽELJKA ČORAK, U funkciji znaka - Drago Ibler i hrvatska arhitektura između dva rata, Zagreb, 1980., 238.

43

IVAN ZEMLJAK, Dom likovnih umjetnika u Zagrebu, Građevinski vjesnik, 2 (1939.), 5.

44

Promjena načina izgradnje Vlaške ulice glede visina 1931., Državni arhiv u Zagrebu, Zbirka regulacijskih planova.

45

STJEPAN PLANIĆ, Problemi savremene arhitekture, Zagreb, 1932., 115.

46

Promjena regulatorne osnove za Krešimirov trg i predio izmedu Krešimirovog trga i Zvonimirove ulice iz 1930., Gradski XVII odsj. za regulaciju grada, Gradski građevni odsjek, Državni arhiv u Zagrebu, Zbirka regulacijskih planova.

47

SANJA GAŠPAROVIĆ - ANA SOPINA, Uloga pejzaža u planiranju Zagreba od početka 20. do početka 21. stoljeća, Prostor, 55 (2018.), 132-145.

48

ZRINKA BARIŠIĆ MARENIĆ, Trg kralja Petra Krešimira IV. u Zagrebu: urbanističko-arhitektonska i perivojna geneza, Prostor, 23 (2002.), 77-92.
49

FEĐA VUKIĆ, Intervju: Zvonimir Vrkljan arhitektonski standard industrijske epohe, Čovjek i prostor, 7-12 (1993.), 18-21.

50

Arhitekt Vladimir Šterk od prije je prisutan na ovom prostoru. Stambeno-poslovnu kuću Omega d. d. u Zvonimirovoj 3 podigao je još 1923./24., a uglovnica Rosinger-Jungwirth izbačenih ugaonih balkona (Draškovićeva 30 - Đorđićeva 23, 1930./31.), jedna od prvih vjesnika moderne arhitekture, na granici je promatranog područja, ali u neizbježnom vizualnom kontaktu s njom. U Zvonimirovoj 15 podignut će od 1935. do 1937., s trijom s kojim je radio Radnički dom na Krešimirovu trgu, dvojnu poslovnu zgradu Javne burze rada, sa stubištima i kancelarijama u izbačenim dvorišnim krilima.

51

BRUNO MILIĆ, Djelo Cirila Jegliča u Zagrebu od 1932. do 1940., Čovjek i prostor, 7-8 (1989.), 31.

52

TOMISLAV TIMET, Stambena izgradnja Zagreba do 1954 godine, Zagreb, 1961.

53

VLADO ANTOLIĆ, Regulacioni plan i direktivna osnova Zagreba, 1949.; Zavod za urbanizam, Direktivna regulatorna osnova 1953.; TOMISLAV TIMET, Prilog poznavanju stambene izgradnje Zagreba, Iz starog i novog Zagreba, 3 (1963.), poseban otisak, 271-279; ZDENKO KOLACIO, Stambena izgradnja u Zagrebu, Arhitektura, 1-3 (1960.), 4-9; Urbanistički zavod grada Zagreba, Urbanistički program Zagreba - smjernice za razvoj, 2. izdanje, Zagreb, 1965.; Zagreb 1963-1967, katalog izložbe, Zagreb, travanj 1967.

54

ALEKSANDER LASLO, Franjo Zvonimir Tišina, Čovjek i prostor, 11-12 (1994.), 20-21; Arhitektura u Hrvatskoj 1945-1985., Arhitektura, 196-199 (1986.), 103.

55

IVICA ŽERJAVIĆ, In memoriam Pavao Baranyai (1912-1984), Čovjek i prostor, 4 (1984.), 4.

56

BRUNO MILIĆ (bilj. 51), 31.

57

HELA VUKADIN DORONJGA, Iskorak Vladimira Turine, katalog izložbe, Zagreb, Muzej grada Zagreba, 2006., 57.

58

TOMISLAV ODAK, Pregled stambene arhitekture u Hrvatskoj 1945-91., Arhitektura, 208-210 (1989-1991.), 40-47.

59

RADOVAN IVANČEVIĆ, Interpolacija: međuvrijednost među vrijednostima ili krivotvorina, Arhitektura, 184-185 (1983.), 82-85.

60

DARJA RADOVIĆ MAHEČIĆ, Jelinek, Slavko, u: Hrvatski biografski leksikon, sv. 6, Zagreb, 2005., 448-449; RENATA MARGARETIĆ URLIĆ, Slavko Jelinek, Zagreb, 2009., 23-29 (poglavlje: Trpimirova: Stanovi za oficire).

61 EUGEN FRANKOVIĆ, Urbanističko planiranje Zagreba od 1945. do 1985., Radovi Instituta za povijest umjetnosti, 9 (1986.), 85-87. 
62

EVE BLAU - IVAN RUPNIK (ur.), Project Zagreb, Barcelona, Actar, 2007., 254-255.

\section{3}

FEDOR KRITOVAC, Uređenje prostora Laginjina - Vojnovićeva ulica, Zagreb, prema programu i sredstvima iz "malih komunalnih akcija", Arhitektura, 166-167 (1978.), 47.

64

SUSANNAH HAGAN, Designing London's Public Spaces. Postwar and now, London, 2019.

65

IVO MAROEVIĆ, Novo u starom u arhitekturi Hrvatske - proces interpolacije, Vijesti muzealaca i konzervatora Hrvatske, 4 (1977.), 68-69.

66

TOMISLAV PREMERL, Ante Glunčić (1931-1985), Čovjek $i$ prostor, 10 (1985.), 28.

67

MIRJANA STIPETIĆ, Urbanistička cjelina Zagreb - istok, Vijesti muzealaca i konzervatora Hrvatske, Zagreb, I. dio, br. 1-6 (1975.), 42; II. dio, br. 1 (1977.), 68.

68

NADA BENIĆ HLEBEC, Razvoj planiranja $i$ zaštite prostora grada Zagreba, elaborat, Regionalni zavod za zaštitu spomenika kulture, Zagreb, 1986.

69

ZDENKO KOLACIO (ur.), Urbanistički zavod grada Zagreba
1956-1976. 20 godina Urbanističkog zavoda grada Zagreba, Zagreb, 1976., 42.

70

BRANKO SILAĐIN - BERISLAV ŠERBETIĆ, Iblerov trg projekt 1977., Arhitektura, 184-185 (1983.).

71

Nagrade 14. zagrebačkog salona, Čovjek i prostor, 6-7 (1979.), 9.

72

NADA BENIĆ HLEBEC, Urbanistički problemi povijesne jezgre grada sa stajališta službe zaštite spomenika kulture, Čovjek $i$ prostor, 9 (1977.), 11.

73

Nagrađeni radovi na natječaju za izradu urbanističko-arhitektonskog rješenja kompleksa "Iblerov trg" u Zagrebu, Čovjek $i$ prostor, 1-6 (1993.), 4.

74

ZDENKO KOLACIO (bilj. 69), 41.

75

Uži natječaj za idejno rješenje poslovnog objekta na uglu Solovljeve i Draškovićeve (1967), Čovjek i prostor, 179 (1967.), 1-5; DARKO VENTURINI, Arhitektonski projektni zavod - APZ, prilog poslijeratnoj hrvatskoj arhitekturi, Zagreb, 1982., 57.

76

RADOVAN IVANČEVIĆ, Druga ofenziva na Kovačića, u: Radovan Ivančević, Za Zagreb (...suprotiva mnogima), Zagreb, 2001., 297-313.

Summary

Darja Radović Mahečić

The Three-Square Sequence

(Croatian Great Men Square - Square of the Victims of Fascism - Krešimir Square) and the Urban Status of the Eastern Extension of Zagreb's Lower Town

The three-square sequence (Croatian Great Men Square Square of the Victims of Fascism - Krešimir Square) is the backbone of the eastern part of Zagreb's city centre. The urban status of this extension of the Lower Town is a result of the evolution of the district that used to be called "the area east of Draškovićeva Street" in the regulation plans, which at the turn of the $20^{\text {th }}$ century meant being outside the framework of the so-called "inner city". The author of the idea of positioning the squares along a diagonal axis (whose function was to connect the city centre with the suburbs) was
Zagreb's most important urban planner at the time, Milan Lenuci, who was the first to highlight the development possibilities of this part of the city. With a detailed regulatory plan in 1905, he defined the key elements of this area, which was almost entirely built in the 1920s and 1930s.

For Lenuci, the new city district started on the corner of historical Jurišićeva and Draškovićeva streets, on the site of the future Stock Exchange Square. The backbone of this new zone was a powerful diagonal axis that included Račkoga and Višeslavova streets, which had its visual starting point in the 
Cathedral towers in the northwest, while in the southeast, next to the railway, the area of the future Branimir Market had already been defined. Along this avenue, Lenuci planned a rectangular square, the future Square of the Victims of Fascism, and the oval-radial Krešimir Square. The former was located at the junction of two busy thoroughfares, Račkoga and the future Zvonimirova streets, and in its finalized form surpassed Lenuci' s projections in terms of proportions, architecture, and traffic importance, as he had originally planned the latter, Krešimir Square more ambitiously.

Unlike the Lower Town, a largely orthogonal urban system built before World War I, the area east of Draškovićeva Street required a differentiated system of communications, defied square schemes, emphasized the picturesqueness of street lines, and expanded the notion of public space and greenery. The intense and high-quality construction of the interwar period, when a new business and residential zone was created here, was elaborated exclusively by partial regulatory plans. Visual contacts with the old city centre and a large number of exceptional architectural achievements gave this district its identity and recognisability, as well as its multiple cultural and historical values. The joint efforts of various protagonists within a relatively short time resulted in one of the most representative exteriors in the urban physiognomy of Zagreb.

After World War I, Zagreb did not have a general master plan, so its modernization was articulated by the 1923 city plan. In economic and architectural terms, the most important event was the construction of the Stock Exchange, for which a short-listed architectural competition was organized in 1920, as it was customary for public buildings. What raised Viktor Kovačić' s award-winning proposal above its competitors was the urban vista it offered, the formation of a "gate" to this new urban area. Thus, the idea of having twin buildings flanking the beginning of Franje Račkoga Street - the Stock Exchange and the House of Engineers - provided not only an entrance to the future district of financial and commercial companies and institutions, but also a more ambitious design for the Stock Exchange Square itself, the first in the sequence along the diagonal axis. The Stock Exchange immediately became a symbol of the new mercantile era and the focus of the new district of monumental business and residential palaces in the style of classical modernism of the 1920s. These were commercial premises with elegant halls on ground floors and mezzanines, luxury apartments on the upper floors and bachelors' rooms in the attics.

The stylistically unique and simultaneous realization of this part of the city was made possible by a generation of Croatian architects trained throughout Central Europe, at a time when Zagreb did not yet have a Technical Faculty. Dionis Sunko specialized in the construction of financial institutions, Aladar Baranyai's houses determined the appearance of the north and east sides of Square of the Victims of Fascism, and the projects of the Cernjak-Neumann duo defined the eastern front of Višeslavova Street. Vjekoslav Bastl produced the characteristic architecture with Ionic pilasters and gables above the façades, while Rudolf Lubynski's buildings had a wide typological range, from the Penkala Factory to his own house. But the architect whose office and apartment buildings particularly determined the appearance of the district with their proportions, elegance, and solidity of execution was Hugo Ehrlich who completed Adolf Loos' Karma villa at Lake Geneva and ran the biggest atelier in town. His monumental apartment superblock in Martićeva Street
(1926-1930) was one of the largest construction projects of that time in Zagreb.

Individual architectural tasks were merged and in the early 1930s unique solutions were sought that included several blocks. The representative assembly of State High Schools in Križanićeva Street (Egon Steinmann, 1930), once the largest building in this part of the city, certainly stood out among them.

It was only when the problems of fragmentary construction, traffic, and hygiene in the city became insurmountable that an international competition for the general regulatory plan of Zagreb was launched in 1930. Urban planners employed on elaborating the General Regulatory Plan of 1936 aimed at modernizing the city centre and planned the district of Trnje, and by that time the area around the Square of the Victims of Fascism had already become the self-proclaimed "New Zagreb".

The House of Croatian Artists, designed by sculptor Ivan Meštrović and the collaborating architects (1934-38), is one of the most important buildings in this part of the city in terms of urban planning and symbolism. Its construction added a powerful new dynamic to the given axis of the three squares and the city district with its appearance and function. The round pavilion was the important landmark that stood out in the characteristic symmetrical view from the Stock Exchange down Račkoga Street, accentuated the centre of the Square of the Victims of Fascism and positioned itself equally towards the surrounding blocks of houses and streets that radiated from it.

Krešimir Square was planned as the starting point of a recognizable diagonal structure and was realized as the largest park square in Zagreb during the interwar period. Although the sporadic construction of the west and east sides of the square with individual houses began in the mid-1920s, it was only with the well balanced urban, architectural, and horticultural design of Vlado Antolić, Josip Seissel, and Ciril Jeglič in the second half of the 1930s that it acquired its paradigmatic features. This was the first awarded and realized project at our first public competition for urban and horticultural design of public urban space in Zagreb (1934). By designing the park with two different units - a smaller north-eastern one, orthogonally composed and featuring a modern children's playground, and a larger south-western one with organically shaped greenery - they created a square that was representative and intimate at the same time. Modern architecture of the 1930s contributed to the transformation of this area with its refined expression and came to dominate the northern side of the square, especially the State Trade Academy designed by Zvonimir Vrkljan (1931-38) and the Workers' House on the corner, work of Vladimir Šterk (1935-38), which determined the character of the square.

Intense construction activity in the period between the two world wars led to the realization of a diagonal sequence of squares and the surrounding blocks: Croatian Great Men Square was built in 1921-1931, Square of the Victims of Fascism in 1922-1937, and Krešimir Square from the 1920s to the 1950 s.

After World War II, this part of the city was considered urbanized and was no longer in the focus of new regulatory plans, but interpolations were designed for the vacant plots. The emphasis was on fragmenting the traditional blocks, pulling the new buildings away from the street line, and expanding 
public space and greenery. Points of special attention were those interpolations that also stood out in terms of height, such as the so-called "Wooden Skyscraper" in Marticeva Street, designed by Drago Ibler (1955-58), and the apartment assembly in Laginjina, work of Ivan Vitić (1958-62). The "rationalization of housing construction" favoured blocks that were outlined within a wider area, such as the residential micro-zone in the eastern part of Martićeva (1948-57) or the apartment towers in Trpimirova (1955-63), in its southern part along the railway, which had traditionally been intended for industry and was therefore still empty.

In a decades-long desire for having the two diagonal streets leading to the Square of the Victims of Fascism, Račkoga and Mislavova, start from Draškovićeva with small triangular squares, the Stock Exchange Square was redesigned in 1994, while its southern counterpart, which had been unattractive for years, was successfully renovated although still lacking the status of a square.

The area between Vlaška and Draškovićeva streets, the railway, and Bauerova, which was first articulated in an urban plan by engineer Milan Lenuci, and which was dominated by the Square of the Victims of Fascism as the middle of the three squares, is one of the most striking in the physiognomy of Zagreb's centre. This representative urban area, which was created due to the involvement of numerous protagonists in a relatively short segment of the $20^{\text {th }}$ century, should be preserved as a mandatory part of the future development programme.

Keywords: Zagreb architecture, urban planning, regulatory plans, Milan Lenuci, Regulatory Plan for the Eastern Part of the City (1905), classical modernism of the 1920s, interwar architecture, interpolation 